\title{
Impacts of Coastal Land Use and Shoreline Armoring on Estuarine Ecosystems: an Introduction to a Special Issue
}

\author{
Diann J. Prosser ${ }^{1}$ (D) Thomas E. Jordan ${ }^{2} \cdot$ Jessica L. Nagel $^{1} \cdot$ Rochelle D. Seitz $^{3}$. \\ Donald E. Weller ${ }^{2}$ Dennis F. Whigham ${ }^{2}$
}

Received: 16 September 2016 /Revised: 3 September 2017 / Accepted: 1 October 2017 / Published online: 18 December 2017

(C) The Author(s) 2017, corrected publication 2019

\begin{abstract}
The nearshore land-water interface is an important ecological zone that faces anthropogenic pressure from development in coastal regions throughout the world. Coastal waters and estuaries like Chesapeake Bay receive and process land discharges loaded with anthropogenic nutrients and other pollutants that cause eutrophication, hypoxia, and other damage to shallow-water ecosystems. In addition, shorelines are increasingly armored with bulkhead (seawall), riprap, and other structures to protect human infrastructure against the threats of sea-level rise, storm surge, and erosion. Armoring can further influence estuarine and nearshore marine ecosystem functions by degrading water quality, spreading invasive species, and destroying ecologically valuable habitat. These detrimental effects on ecosystem function have ramifications for ecologically and economically important flora and fauna. This special issue of Estuaries and Coasts explores the interacting effects of coastal land use and shoreline armoring on estuarine and coastal marine ecosystems. The majority of papers focus on the Chesapeake Bay region, USA, where 50 major tributaries and an extensive watershed $\left(\sim 167,000 \mathrm{~km}^{2}\right)$, provide an ideal model to examine the impacts of human activities at scales ranging from the local shoreline to the entire watershed. The
\end{abstract}

Diann J. Prosser

dprosser@usgs.gov

1 Patuxent Wildlife Research Center, Beltsville Laboratory, U.S. Geological Survey, 10300 Baltimore Avenue, Beltsville, MD 20705, USA

2 Smithsonian Environmental Research Center, 647 Contees Wharf Road, Edgewater, MD 21037, USA

3 Virginia Institute of Marine Science, College of William \& Mary, PO Box 1346, Gloucester Point, VA 23062, USA papers consider the influence of watershed land use and natural versus armored shorelines on ecosystem properties and processes as well as on key natural resources.

Keywords Shoreline armoring · Chesapeake Bay · Land use · Coastal development · Nearshore habitat · Land-water interface

Shallow estuarine waters are biologically active interfaces between the land and the sea that provide many beneficial ecosystem services for diverse aquatic and terrestrial animal communities (Costanza et al. 1997; Orth et al. 2006; Barbier et al. 2011). Shallow nearshore habitats, including non-vegetated shallows, tidal wetlands, and submerged aquatic vegetation (SAV), serve as critical feeding and nursery habitats for many fisheries species (Ruiz et al. 1993; Beck et al. 2001; King et al. 2005; Seitz et al. 2014; Sheaves et al. 2015) as well as important seasonal habitats for migratory species (Erwin 1996). These habitat functions enhance energy flow to higher trophic levels (Dittel et al. 1995; Miller et al. 1996; Clark et al. 2003; Heck et al. 2008).

Nearshore habitats are being degraded by multiple stressors. Shoreline armoring, land development, and invasive species threaten the economically and ecologically important species that depend on these habitats. Here, we focus on temperate estuaries and the effects of human land use and shoreline armoring on the interacting biotic components of the land-water interface, including tidal wetlands, SAV, and fauna, such as benthic invertebrates, epibenthic crustaceans, fish, and waterbirds. These biotic components are influenced by the physical properties of the shoreline and by water quality, which, in turn, is influenced by inputs from the watershed and exchanges with adjacent estuarine water. 
The expansion of coastal human development and armored shorelines throughout the world (Ache et al. 2013; Gittman et al. 2015) creates a growing need for information on the interacting effects of land use and shoreline armoring on nearshore ecosystems.

The world's population is concentrated near coastlines, and that concentration is increasing (Vitousek et al. 1997; Small and Nicholls 2003; Ache et al. 2013; Paerl et al. 2014). Human activities in the nearshore zone can have significant negative impacts on water quality and nearshore habitats. Runoff of nitrogen $(\mathrm{N})$ and phosphorus (P) from urban and agricultural watersheds (e.g., Jordan et al. 2003; Weller et al. 2003) threatens estuarine habitats worldwide through increased algal production, decreased water clarity, and increased occurrence of hypoxia (Doney 2010; Howarth et al. 2011). One major consequence of decreased water quality has been the decline in SAV and associated fauna (Bologna and Heck 1999; Orth et al. 2006; Waycott et al. 2009; Brady and Targett 2013). Nutrient enrichment also impacts coastal wetlands by enhancing the spread of invasive species, such as the Common Reed Phragmites australis (hereafter Phragmites) (Silliman and Bertness 2004; Kettenring et al. 2015), or by reducing root production, which negatively impacts wetland accretion (Langley et al. 2009) and the integrity of intertidal wetland banks (Deegan et al. 2012).

Shoreline alteration, especially armoring, is another important aspect of land use that affects shallow-water coastal systems. The threats of erosion and property loss from storm surge and sea-level rise motivate land owners to install hardened structures to preserve their properties (Dugan et al. 2011; Gittman et al. 2015). These include vertical seawalls or bulkheads (wooden, concrete, or vinyl walls); riprap revetments (granite or concrete stones or boulders placed at an angle); or other structures, such as piers, breakwaters, or low-crested coastal defense structures (Fig. 1). Some coastal cities have $50 \%$ or more of their shorelines armored (Patrick et al. 2014; Gittman et al. 2016b).

There are unintended consequences of shoreline armoring for natural communities. Natural vegetation is replaced resulting in the loss of important habitat services, such as provision of refuge for fauna (Duhring 2008) (Fig. 2). Secondary effects of armoring differ with the type of structure installed. For example, bulkheads reduce filtration of upland run-off by severing the land-water interface (Currin et al. 2010) and may also be sites where enhanced wave reflection erodes sediment and deepens nearshore habitats (NRC 2007; Toft et al. 2007) (Fig. 2). On the other hand, riprap may allow limited exchange of nutrients with the upland and also provide habitat for some biota (Seitz et al. 2006; Davis et al. 2008; Bilkovic and Mitchell 2013; Balouskus and Targett 2016). The combination of coastal erosion and upland development results in "coastal squeeze," whereby low-lying, intertidal areas that would normally retreat inland in the face of sea-level rise are reduced because man-made structures block that retreat (Doody 2004; Pontee 2013; Kirwan et al. 2016). Detrimental effects of shoreline armoring for coastal ecosystems worldwide are becoming well known (Bulleri 2006; Airoldi and Beck 2007; Gittman et al. 2016b) and can include loss of biodiversity and production (Seitz et al. 2006; Bilkovic and Roggero 2008; Dugan et al. 2008; Peterson and Lowe 2009).

Many coastal states in the USA now have incentives or requirements to install "living shorelines" instead of traditional armored structures. Living shorelines incorporate natural elements such as wetland plantings, coral reefs, or shellfish reefs along the shoreline (Temmerman et al. 2013). The natural elements can also be combined with structures like a riprap sill, coir fiber logs with sand fill, oyster shell bags, or shellfish reef just offshore (Figs. 1f and 2) (Duhring 2008). Living shorelines have become increasingly popular because they perform as well as bulkhead or riprap at controlling erosion (Currin et al. 2010; Gittman et al. 2014, 2016a). Moreover, the added natural elements increase habitat value for fauna, maintain nearshore depth and sediment type, and sequester carbon while improving protection from erosion (Davis et al. 2015; Bilkovic et al. 2016). Local hydrodynamics, tidal range, elevation, shoreline geomorphology, and sediment characteristics can all influence the living shoreline design at a specific site (Roberts 2008; Currin et al. 2015; Sutton-Grier et al. 2015). While innovations to improve both the erosion protection and the ecological benefits of living shoreline designs are ongoing, further research and long-term monitoring of the effectiveness of these structures for protecting shorelines will be essential for informing future management decisions (Bilkovic et al. 2016).

\section{Focus of the Special Issue}

This special issue considers the interacting impacts of coastal land use and shoreline armoring on estuarine and coastal marine ecosystems. We synthesize recent research to better understand the interacting effects of shoreline armoring and watershed land use on estuarine resources and processes. The 13 research papers address the effects of different watershed land uses (development, agricultural, forested) and different man-made shoreline types (bulkhead, riprap) compared to natural shorelines (beaches, natural wetlands, wetlands dominated by the invasive species Phragmites) on ecosystem properties (water quality, hydrodynamics, nutrient dynamics, and biogeochemistry) and on key natural resources (SAV, wetlands, benthic communities, macroinvertebrates, fishes, and waterbirds). The final paper presents our efforts to integrate research and management. 
Fig. 1 Examples of shorelines dominated by $\mathbf{a}$ bulkhead, $\mathbf{b}$ riprap revetment, $\mathbf{c}$ beach, $\mathbf{d}$ natural wetland, e Phragmites australis wetland, and $\mathbf{f}$ living shoreline. Photo of the living shoreline was taken 5 years after construction. The poles are the remnants of the temporary fencing installed to protect the wetland plants from goose predation after planting and to deter boats from landing on the beach

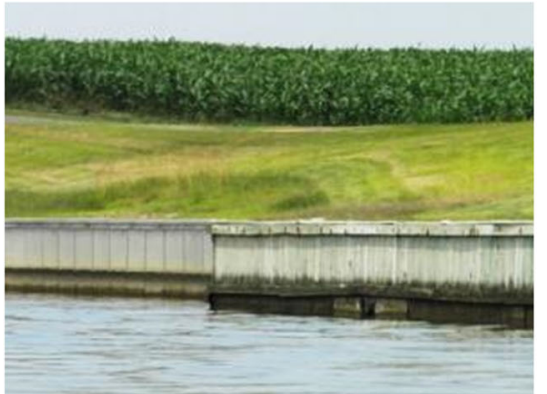

a) Bulkhead

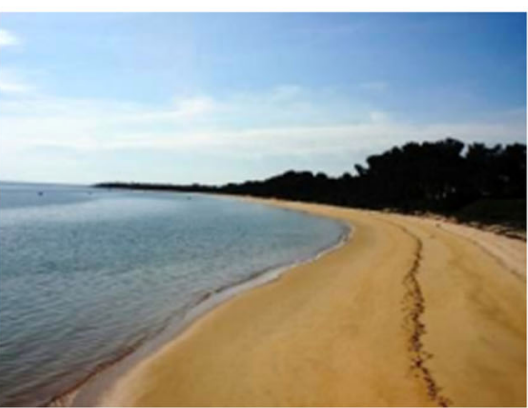

C) Beach

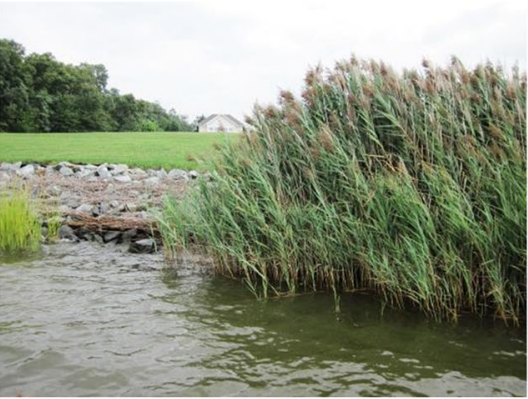

e) Phragmites Wetland

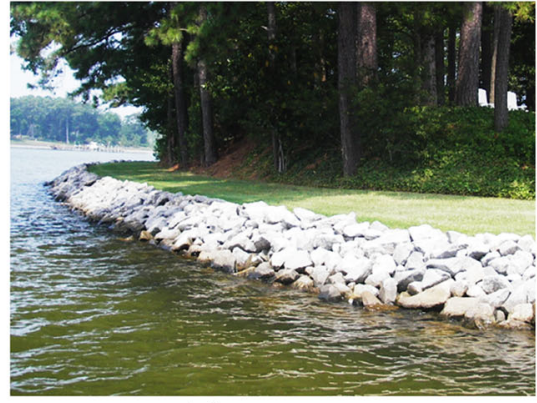

b) Riprap

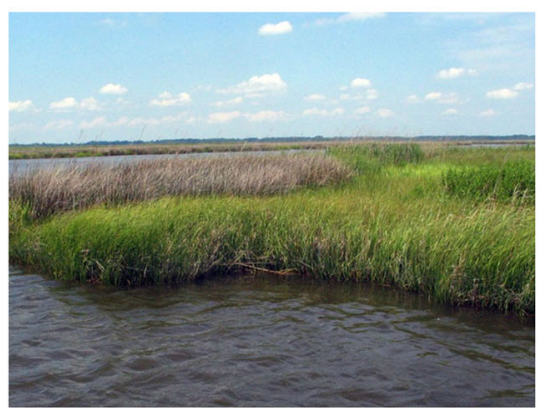

d) Natural Wetland

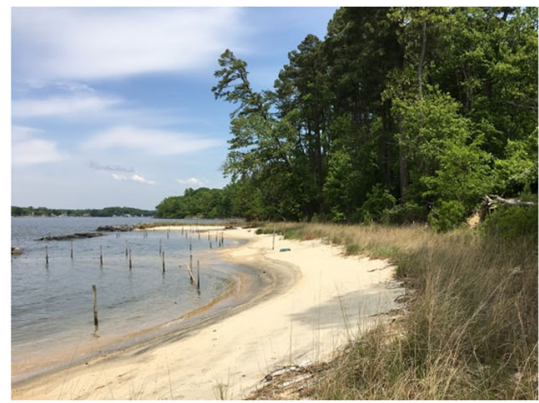

f) Living Shoreline
All but two of the papers result from a 7-year, multiinvestigator, interdisciplinary research collaboration among 19 principal investigators from eight institutions. The project evaluated the physical and ecological influences of watershed land use and shoreline development along the entire salinity gradient of the largest bay in the USA, Chesapeake Bay, and in ocean embayments along the mid-Atlantic coast. The research used a comparative approach exploiting the many subestuaries in this region. The Chesapeake Bay (Fig. 3) has 50 major tributaries and a $167,000 \mathrm{~km}^{2}$ watershed, providing an ideal model to examine the impacts of human activities at scales ranging from the entire system to local alterations of land use or shorelines (the focal scale for many contributions in this volume). Each subestuary, or embayment with at least one perennial tributary, has its own local watershed (Li et al. 2007). Subestuaries differ widely in their watershed land uses and occur across the full range of salinity (Fig. 3), making them convenient, replicated study units for comparing systems dominated by different land uses and salinity regimes (e.g., Li et al. 2007;
Patrick et al. 2014). Subestuaries can also be replicate units for analyzing the effects of other stressors on estuarine responses. For example, subestuary comparisons have been applied to studies of SAV (Li et al. 2007; Patrick et al. 2014), blue crab and bivalve abundance (King et al. 2005), polychlorinated biphenyl (PCB) contamination of fish (King et al. 2004), bird community diversity (DeLuca et al. 2004), and the invasion of wetlands by a non-native form of Phragmites (King et al. 2007). The two papers that were not part of the interdisciplinary project (Dugan et al. 2017; Gehman et al. 2017) were chosen to complement the other papers.

\section{Physical Effects of Armoring}

Armoring strongly modifies the interactions of waves with shoreline habitats, causing changes in physical structure and sediment composition; and these effects depend on the type of armoring, wind and tidal patterns, and the type of sediment substrate. While breakwaters can reduce physical energy at the 

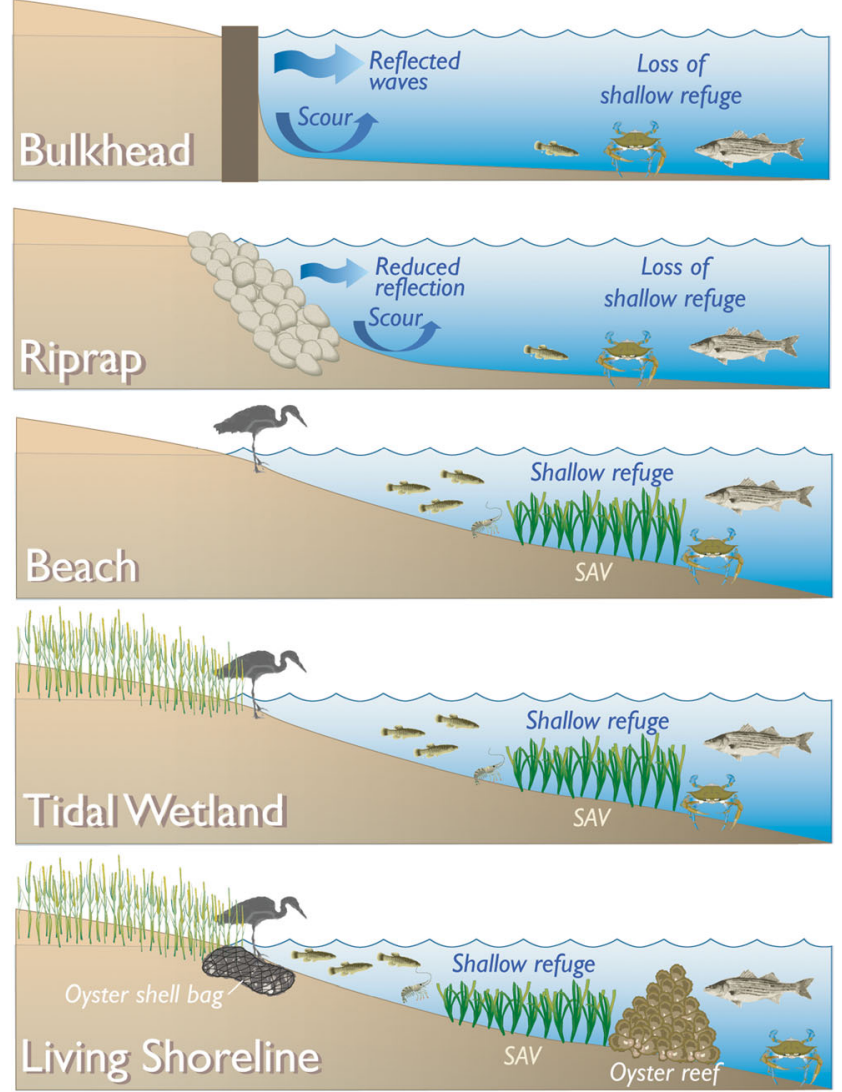

Fig. 2 Potential differences in habitat value among armored, natural, and living shorelines. Natural shorelines (beach and tidal wetlands) and adjacent submerged aquatic vegetation (SAV) beds provide resources and refuge for many estuarine species. Armoring shorelines with bulkhead or riprap may destroy these habitats and the associated shallow-water refuge. A living shoreline incorporates natural elements such as wetland plantings reinforced with oyster shell bags along the shoreline and a shellfish reef just offshore

shoreline, bulkheads and riprap can increase energy at the shoreline by reflecting waves (Plant and Griggs 1992; Miles et al. 2001; Strayer and Findlay 2010) (Fig. 2). Increased energy can, in turn, increase nearshore erosion and sediment export, which deepen the adjacent littoral zone (Dugan et al. 2011). Armored shorelines can also block supplies of fine or organic particles and new terrestrial material to the nearshore zone (Pilkey and Wright 1988; Griggs 2005; Nordstrom 2014). This can result in coarser sediments (Jennings et al. 2001; Gabriel and Bodensteiner 2012; Strayer et al. 2012), narrowing of beach zones (Hall and Pilkey 1991; Fletcher et al. 1997; Dugan et al. 2008), and reduced accumulation and retention of marine wrack and terrestrial organic debris (Heerhartz et al. 2014) along armored shores. Ultimately, any of these changes to hydrodynamic and sediment depositional processes may influence the extent and position of nearshore habitats (e.g., sandy beaches, wetlands, and SAV beds) adjacent to armored shorelines (Bulleri and Chapman 2010).

A better understanding of the factors influencing local hydrodynamics and erosion rates is essential for informing decisions about shoreline management (e.g., type and extent of structures) in a given region. In this issue, Sanford and Gao (2017) (Influences of wave climate and sea level on shoreline erosion rates in the Maryland Chesapeake Bay) investigated spatial correlations between wave forcing, sea-level fluctuations, and shoreline erosion. Using the Simulating Waves Nearshore (SWAN) model and a parametric wave model from the USEPA Chesapeake Bay Program, they combined wave and sea-level data sets with estimates of historical shoreline erosion rates and shoreline characteristics at two different spatial resolutions to explore the factors affecting erosion. Wave power had the most significant influence on erosion, but many other local factors were also implicated. Wetland shorelines showed a more homogeneous, approximately linear relationship between wave power and erosion rates and also appeared to erode faster than bank shorelines for similar wave powers and bank heights. Derived relationships tended to be scale-dependent and spatially variable, so comprehensive local data sets may be necessary for building detailed local predictive relationships.

\section{Effects of Land Use on Nearshore Water Quality}

Human land use activities have important effects on coastal water quality. Sediments generated by agricultural activities, forest loss, and impervious surfaces are delivered to the coast and reduce water clarity. Nutrient pollution (N and $\mathrm{P}$ ) from agricultural activities, developed lands, point sources (e.g., sewage treatment plants and industry), and atmospheric deposition all contribute to coastal eutrophication (Nixon 1995; Doney 2010; Howarth et al. 2011; Paerl et al. 2014), a central problem in many coastal estuaries (Nixon 1995; de Jonge et al. 2002; Scavia and Bricker 2006). In some regions, such as the Chesapeake Bay (Boesch et al. 2001; Kemp et al. 2005), federal mandates have been established to reduce high nutrient inputs (USEPA 2010).

Anthropogenic changes in water quality degrade ecological health, reduce the value of commercially important fisheries, and lower the capacity of coastal systems to provide other ecosystem services. Nutrient pollution from agriculture and fossil fuel combustion stimulates the growth of aquatic plants, including phytoplankton, nuisance algae, harmful algal blooms, epiphytes, and invasive macrophytes (Doney 2010; Howarth et al. 2011). Phytoplankton in the water column and epiphytes on leaves reduce the light available for survival and growth of aquatic macrophytes (Orth et al. 2006). Changes in the phytoplankton and macrophyte communities alter aquatic food webs and change the habitats of fish, benthic fauna, shellfish, and birds (Kemp et al. 2005). Phytoplankton decomposition drives hypoxia, which reduces the growth and survival of aquatic fauna (Diaz and Rosenberg 2008). Toxic algal blooms can kill fish and impact human health (Glasgow et al. 1995), and toxic pollutants like mercury 
Fig. 3 The Chesapeake Bay and mid-Atlantic Coastal Bays. The local watersheds of tributary subestuaries (black outlines) are colored by dominant land use and stippled by the salinity zone of the subestuary (TF: tidal fresh, $\mathrm{OH}$ : oligohaline, $\mathrm{MH}$ : mesohaline, or PH: polyhaline). Delineations of subestuaries and their local watersheds and the categorizations of dominant land uses and salinity zones are described in Li et al. (2007) and Patrick et al. (2014). The inset shows the outline of the Chesapeake watershed (gray line) relative to six states in the eastern USA and Washington DC (red dot)

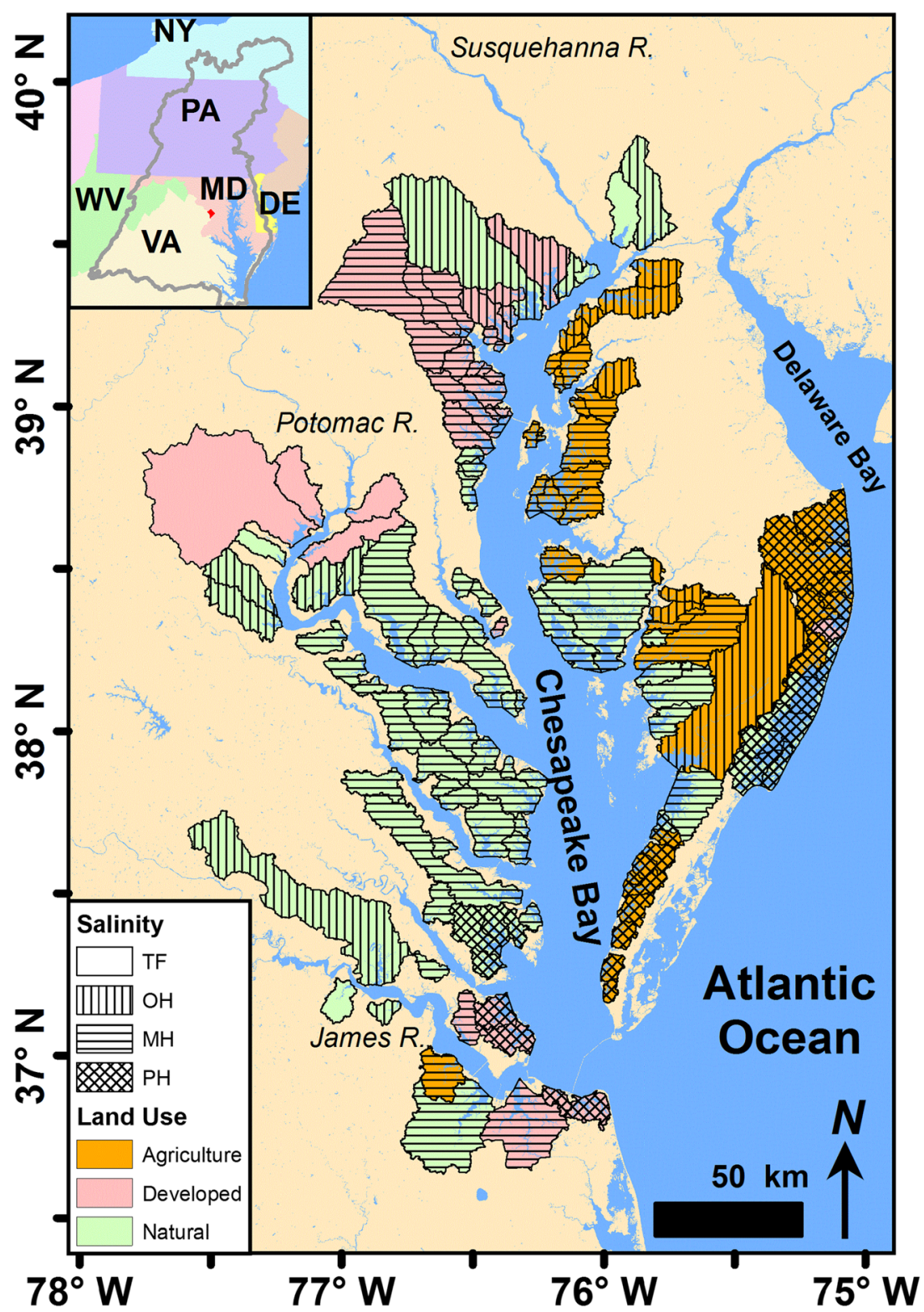

and PCBs contaminate food webs, further stress fauna, and make seafood less suitable for human consumption (Domingo and Bocio 2007).

In this issue, Jordan et al. (2017) (Effects of local watershed land use on water quality in mid-Atlantic coastal bays and subestuaries of the Chesapeake Bay) compared water quality at shallow, nearshore locations in 49 Chesapeake subestuaries and mid-Atlantic coastal bays with differing local watershed land use. Concentrations of total $\mathrm{N}$, dissolved ammonium, dissolved inorganic $\mathrm{N}$, and chlorophyll- $a$ were positively correlated with the percentages of urban and agricultural land in the watershed. Total phosphorus (TP) and dissolved phosphate also increased with agricultural land but were not affected by urban land use. These relationships indicate the importance of land use in the local watershed and suggest that $\mathrm{N}$ is the limiting nutrient for chlorophyll- $a$ production in these systems. In addition, nearshore water quality inside the subestuaries generally differed from that measured in adjacent tidal waters, with TP, organic N, and chlorophyll- $a$ concentrations much higher inside the subestuaries, while nitrate concentrations were much higher outside. Therefore, these findings suggest that the importance of local land use and the distinctive biogeochemical environment of nearshore waters should be considered in managing coastal systems.

\section{Effects of Shoreline Armoring and Land Use on Tidal Wetlands}

Tidal wetlands provide many ecosystem services, including carbon sequestration (Drake et al. 2015; Pastore et al. 2017), filtering nutrients and suspended sediments from agricultural or urban runoff (Nixon 1980; Howes et al. 1996; Comin et al. 
1997), and supporting diverse faunal communities (Chapman 2003; Parikh and Datye 2003; Scyphers et al. 2015). Natural wetlands can protect upland communities by attenuating waves, capturing and accreting sediment, reducing erosion, and mitigating storm surge (Spalding et al. 2014). The degradation of coastal wetlands from human activities has slowed in the USA (Dahl 2011), but wetlands are still threatened by sea-level rise and erosion (Kirwan and Megonigal 2013; Blankespoor et al. 2014). Permanent armored structures alter connectivity through habitat fragmentation and block the landward migration of natural shoreline habitats in response to sea-level rise ("coastal squeeze"), leading to further loss of coastal habitat (Doody 2004; Bozek and Burdick 2005; Pontee 2013). Thus, there continues to be a need to conserve and restore coastal wetlands (Zedler 2004; Wigand and Roman 2012; Thorne et al. 2015), while identifying and disentangling the major drivers of wetland loss.

In this issue, Gehman et al. (2017) (Effects of small-scale armoring and residential development on the salt marshupland ecotone) compared the biota and physical and environmental characteristics of 60 tidal wetlands adjacent to bulkheads, residential backyards with no armoring, or intact forests in a cross-disciplinary study along the US Georgia coast. Elevation was lower in wetlands adjacent to bulkheads, and these sites had features typical of lower elevation wetland habitats. Wetlands adjacent to unarmored residential sites had higher soil water content and lower porewater salinity than armored or forested sites, indicating increased freshwater input to the sites. Along the wetland-upland ecotone, deposition of wrack was negatively related to elevation at armored sites but positively related at unarmored residential and forested sites. Densities of the high marsh crab Armases cinereum (a species that moved readily across the wetland-upland ecotone at forested sites) were lower at armored and unarmored residential sites. These results suggest that minimizing armoring while retaining some forest vegetation at the wetland-upland interface could reduce these impacts.

Human-altered ecosystems can be more susceptible to invasion by non-native species than natural systems (Hobbs 2000). A particularly aggressive invasive species in disturbed coastal systems is the European haplotype of Phragmites (Lelong et al. 2007). This species invades humandominated landscapes, such as highway corridors (Jodoin et al. 2008; Leblanc et al. 2010), levees along impoundments (Bart and Hartman 2000), developed shorelines (Silliman and Bertness 2004), and constructed wetlands (Havens et al. 2003). In addition, Phragmites has invaded natural wetlands along the US east coast (Chambers et al. 1999) and in the continental US (Kulmatiski et al. 2010; Larson et al. 2011; Bourgeau-Chavez et al. 2013). Invasion by Phragmites can negatively impact wetland structure and function by altering dynamics in fish (Jones et al. 2014; Jones and Able 2015) and bird (Prosser et al. 2017, this issue) communities. However, the consequences of invasion may not all be negative because Phragmites patches are not biological deserts, especially for animals (Kiviat 2013; Dibble and Meyerson 2014). The high growth rate of Phragmites may also contribute to sequestration of carbon and nitrogen (Kiviat 2013) and enable wetlands to keep pace with sea-level rise and minimize resulting wetland loss (Rooth and Stevenson 2000), which may be especially important in regions where the rate of sea-level rise is high (Williams 2013).

Many studies have explored the underlying causes for the rapid expansion of Phragmites. Earlier research focused on rhizome dispersal and establishment (e.g., Philipp and Field 2005; Bart et al. 2006), but it is now clear the primary mode of spread is the production, dispersal, and establishment of plants from seeds (e.g., Wilcox 2012). The mechanisms behind the rapid expansion of Phragmites have been particularly well studied in Chesapeake Bay brackish tidal wetlands, and three key factors appear to promote local expansion. First, natural and human-related disturbances create physical spaces where seedlings can become established. Second, multiple genotypes must be present because Phragmites can only produce seeds by cross-pollination between different genotypes (Kettenring et al. 2011). Third, elevated nitrogen levels promote expansion because seedlings grow faster, more ramets produce inflorescences, and inflorescences have more flowers, resulting in higher seed production (Kettenring et al. 2015).

Watershed land use has also been important to the expansion of Phragmites through its relationship to physical disturbance and elevated nitrogen. The abundance of Phragmites in brackish wetlands was positively related to the amounts of developed and agricultural land in watersheds that drained into the wetlands, and the closer those land use types were to the subestuary, the higher was the abundance of Phragmites (King et al. 2007). Sciance et al. (2016) found that agricultural land use and shoreline armoring were significant predictors of Phragmites occurrence; and Silliman and Bertness (2004) linked the abundance of Phragmites to the development of adjacent upland habitats and nitrogen loading to an estuary.

Management strategies to control Phragmites have been proposed (Hazelton et al. 2014; Kowalski et al. 2015), but there is little information on recovery of native vegetation following Phragmites removal. In this issue, Hazelton et al. (2017) (Spatial and temporal variation in brackish wetland seedbanks: implications for wetland restoration following Phragmites control) investigated whether management efforts to remove Phragmites may act as a disturbance, potentially fostering reinvasion. They surveyed the soil seedbank of three vegetation cover types in plots from which Phragmites had been removed by 2 years of herbicide treatment, plots in which Phragmites was left intact, and plots with native, reference vegetation in five Chesapeake Bay subestuaries. Surprisingly, the seedbank composition was not influenced 
by vegetation cover type. Instead, seedbanks in plots within a subestuary resembled each other more than did treatments across subestuaries, indicating that seedbanks are fairly homogenous within a subestuary. While these diverse seedbanks could lead to invasion-resilient wetland communities, the prevalence of undesirable species in the seedbank may speed up their re-establishment following invasive plant removal if passive revegetation is the primary means of restoration.

\section{Stressors of Submerged Aquatic Vegetation (SAV)}

SAV is a foundational component of coastal systems, and it delivers many ecosystem services. SAV provides structural habitat and refuge from predators for invertebrates and small fish (Hemminga and Duarte 2000; Gillanders 2006) as well as providing foraging habitat for waterbirds (Erwin 1996; Valentine and Heck 1999). It also stabilizes benthic substrates and moderates shoreline erosion (Madsen et al. 2001; de Boer 2007), and it improves water quality and clarity by removing nutrients (Wigand et al. 2001; Moore 2004), reducing $\mathrm{CO}_{2^{-}}$ driven acidification (Unsworth et al. 2012), and reducing resuspension of sediments (Gruber and Kemp 2010). However, SAV is imperiled worldwide by multiple stressors, including sediment and nutrient runoff, physical disturbance, and climate change (Duarte 2005; Orth et al. 2006; Waycott et al. 2009; Short et al. 2011; Lefcheck et al. 2017; Orth et al. 2017). In many estuaries, the spatial extent of SAV is far below historic levels (Orth and Moore 1983; Waycott et al. 2009; Orth et al. 2010; Short et al. 2014), and increasing SAV coverage is frequently a central goal of restoration efforts (Batiuk et al. 2000; Chesapeake Bay Executive Council 2003; van Katwijk et al. 2009; Chesapeake Bay Program 2014; Orth et al. 2017).

The linkages between water clarity and SAV are well understood (Boesch et al. 2001; Kemp et al. 2004; Kemp et al. 2005; Waycott et al. 2005; Greening and Janicki 2006; Patrick and Weller 2015; Orth et al. 2017). However, the complex relationships between SAV abundance and land use distributions have only recently been quantified ( $\mathrm{Li}$ et al. 2007; Patrick et al. 2014, 2016). SAV abundance is generally higher in estuaries with watersheds that are forested than those dominated by development and agriculture ( $\mathrm{Li}$ et al. 2007; Patrick et al. 2014), but effects may vary with weather patterns and SAV community type. For example, agricultural impacts on SAV may be stronger in wet years when higher runoff from agricultural lands delivers more nutrients and sediments to subestuaries ( $\mathrm{Li}$ et al. 2007). In Chesapeake Bay, the negative effects of cropland or developed land are generally stronger in polyhaline SAV communities, possibly because polyhaline SAV species are more sensitive than oligohaline species to stressors that reduce water clarity (Patrick et al. 2014; Patrick and Weller 2015).
Shoreline armoring also has negative impacts on SAV (Gabriel and Bodensteiner 2012; Findlay et al. 2014; Patrick et al. 2014; Patrick and Weller 2015). Armoring is associated with erosive habitat loss, deepening of the nearshore zone, and increased suspended sediments (Pilkey and Wright 1988; Miles et al. 2001; Findlay et al. 2014) that reduce growth and survival of SAV (Moore et al. 1997; Moore and Jarvis 2008). However, the effects of armoring also vary with land use, type of shoreline armoring, and SAV community type (Patrick et al. 2014; Patrick and Weller 2015). Patrick et al. (2014) reported that the SAV abundance throughout a subestuary was negatively related to the percentage of the riprap along the shoreline, but that this relationship could be confounded with the effects of other stressors (e.g., higher wave energy, more developed land, more boat traffic, etc.) that are correlated with the percentage of the riprap. In another study, SAV abundance was lower adjacent to armored shorelines in some settings, but the effects of armoring differed among salinity zones and dominant land use in local watersheds (Patrick et al. 2016).

Two papers in this special issue explored the complex relationships between land use, shoreline armoring, and SAV abundance. Building on previous work (Patrick et al. 2014, 2016, Patrick and Weller 2015), Patrick et al. (2017) (Land use and salinity drive changes in SAV abundance and community composition) analyzed long-term SAV data to better understand how watershed land use, shoreline alteration, salinity, and SAV community composition affect trends and inter-annual variation in SAV abundance. An ordination identified five SAV community types throughout Chesapeake Bay subestuaries. Some subestuaries maintained the same community through time, but in others, the community type changed across years. Community type influenced the rate of SAV recovery in subestuaries more strongly than the other stressors, but the amounts of urban or agricultural land in the local watershed did significantly reduce the rate of recovery. The strength of the land use effect differed among community types and was strongest in the mixed freshwater community.

Landry and Golden (2017) (In-situ effects of shoreline type and watershed land use on submerged aquatic vegetation habitat quality in the Chesapeake and Mid-Atlantic coastal bays) sought to determine if shoreline armoring degrades SAV habitat quality at the local scale. In situ comparisons of SAV beds adjacent to natural and armored shorelines in 24 subestuaries throughout the Chesapeake and Maryland's Coastal Bays indicated that species diversity, density, and bed width were significantly reduced by the presence of riprap. A post-hoc analysis also confirmed that humandominated land use in the surrounding watershed negatively influenced SAV habitat. These results suggest that the expansion of shoreline armoring and human-dominated land use will threaten SAV in this region. 


\section{Effects of Shoreline Armoring and Land Use on Benthic Fauna and Fish}

A wide variety of benthic invertebrates, fish, and crabs utilize shallow-water, nearshore habitats for foraging, nursery grounds, or refuge from predation (Ruiz et al. 1993; Beck et al. 2001; Seitz et al. 2014). These organisms are key components of estuarine food webs and also include many commercially important species (King et al. 2005), so the loss or degradation of coastal habitats in association with human land use activities and shoreline armoring may have profound impacts on estuarine faunal communities.

Faunal communities in shallow-water habitats can be severely affected by shoreline modifications. For example, diversity and biomass of benthic fauna are often lower along armored compared to natural shorelines (Tourtellotte and Dauer 1983; Seitz et al. 2006; Bilkovic and Roggero 2008; Morley et al. 2012; Balouskus and Targett 2016; Gittman et al. 2016b). Armored shorelines can impact fauna by reducing vegetated habitats and deepening adjacent waters (Miles et al. 2001; Bozek and Burdick 2005; Dugan et al. 2008; Walker et al. 2011) or introducing toxins in chemically treated construction materials (Weis et al. 1998). Epibenthic predators can be influenced by bottom-up control, so they may be reduced in habitats with depauperate benthic infaunal communities (Bilkovic et al. 2006; Seitz et al. 2006; Davis et al. 2008). However, the effects on larger nekton may not be evident until three or more years after shoreline habitat alteration (La Peyre et al. 2014).

At larger scales, the degradation of water quality associated with upland development and agricultural use of watersheds can lead to less diverse habitats, reductions in nearshore faunal abundance, biomass and diversity, and systems with less-complex food webs (Holland et al. 2004; Kemp et al. 2005; King et al. 2005). Increased runoff of nutrients, pollutants, and contaminants from upland development (Jordan et al. 1997; Gregg et al. 2015) can reduce the abundance of pollutionsensitive species (Weisberg et al. 1997; King et al. 2005). Agricultural nutrient runoff also can lead to hypoxic events in warm, shallow waters (Tyler et al. 2009), which can negatively affect benthic invertebrates and nekton (Rabalais and Turner 2001; Eby and Crowder 2004; Diaz and Rosenberg 2008; Breitburg et al. 2009). In some areas where as little as $12 \%$ of the watershed was developed, the benthic community was negatively impacted (Dauer et al. 2000; Bilkovic et al. 2006). These larger landscape-level effects may either mask (Lawless and Seitz 2014; Lovall et al. 2017) or exacerbate (Seitz and Lawless 2008; Seitz et al. 2017, this issue) the effects of smaller-scale habitat alterations (e.g., shoreline armoring) on benthic infauna, fish, and crab abundance.

Six papers in this special issue investigated the effects of land use or shoreline armoring on macrofaunal communities. Seitz et al. (2017) (Human influence at the coast: Upland and shoreline stressors affect coastal macrofauna and are mediated by salinity) examined how subestuary land use and shoreline development affected density, biomass, and diversity of benthic infaunal communities in 14 subestuaries of Chesapeake Bay. Benthic biomass was significantly lower in subestuaries with developed compared to forested upland use. Infaunal biomass declined exponentially with the proportion of nearshore developed land because large, pollution-sensitive species declined, whereas the density of small, pollutiontolerant species increased. For large macrofauna (>3 mm), density did not differ significantly among natural wetland, beach, and riprap habitats, but tended to be lower adjacent to bulkhead shorelines, particularly in low-salinity $(<15 \mathrm{psu})$ subestuaries. Benthic diversity tended to be highest adjacent to natural wetlands compared to other habitats in low-salinity subestuaries. Upland and shoreline development were both important in driving patterns in benthic community structure in multi-model comparisons. These results suggest that minimizing subestuary upland development and shoreline armoring may be essential for maintaining productive benthic communities within the estuarine food web.

Crum et al. (2017) (Growth and movements of mummichogs (Fundulus heteroclitus) along armored and vegetated estuarine shorelines) assessed the impact of shoreline alteration on an estuarine fish by comparing growth and movement along stretches of shorelines dominated by Spartina alterniflora, Phragmites, riprap, and bulkhead in a tributary of the Delaware Coastal Bays. Fish were individually tagged and displayed a high degree of site fidelity overall. Growth rates were greatest along riprap, intermediate at bulkhead, and lowest along Spartina- and Phragmites-dominated shorelines. Combining these growth rates with density data from a concurrent study (Balouskus and Targett 2017, this issue) yielded the highest estimates of relative $F$. heteroclitus productivity along Spartina and Phragmites shorelines, intermediate at riprap, and lowest along bulkhead, suggesting that armoring reduces abundance sufficiently to negatively affect localized productivity of this species.

Balouskus and Targett (2017) (Impact of armored shorelines on shore-zone fish density in a mid-Atlantic, USA, estuary: modulation by hypoxia and temperature) demonstrate how nearshore habitat use by estuarine fish species is driven by both physical habitat structure (shoreline structure) and water characteristics such as dissolved oxygen and temperature. During times of low dissolved oxygen and increased water temperature, many fish species had higher fidelity to natural wetland habitat (Spartina alterniflora) compared with armored (riprap, bulkhead) and Phragmitesdominated shorelines. This suggests that a combination of stressors, including altered shorelines and reduced water quality, affects fish habitat usage.

Kornis et al. (2017) (Shoreline hardening affects nekton biomass, size structure and taxonomic diversity in nearshore 
waters, with responses mediated by functional species groups) evaluated mobile fish and shellfish assemblages within two nearshore habitat zones adjacent to natural (native wetland or beach) and armored (bulkhead or riprap) shorelines. Within 0-3 $\mathrm{m}$ from shore, total biomass was greatest at bulkhead and riprap shoreline types, driven by species from the planktivore (e.g., bay anchovy) and benthivorepiscivore (e.g., white perch) functional groups, whereas small-bodied littoral-demersal species (e.g., Fundulus spp.) had greatest biomass at wetland habitat. In contrast, total fish biomass was comparable among all four shoreline types within $16 \mathrm{~m}$ from shore, suggesting the effect of shoreline armoring on fish biomass is most pronounced immediately at the land/water interface. Utilization of shoreline type was also mediated by body size across all functional groups, with individuals $\leq 60 \mathrm{~mm}$ most abundant at wetlands and beaches and individuals $>100 \mathrm{~mm}$ most abundant at armored shorelines. Taxonomic diversity was lowest at beach shoreline types within 0-3 $\mathrm{m}$ from shore, but greatest at wetlands and beaches within $16 \mathrm{~m}$ from shore. The study highlights substantial differences in fish and mobile shellfish biomass density along armored versus natural shorelines, and illustrates how assemblage composition and diversity are mediated by both shoreline type and body size.

Dugan et al. (2017) (Generalizing ecological effects of shoreline armoring across soft sediment environments) compared the effects of shoreline armoring structures across soft sedimentary habitats using a conceptual model that scaled the predicted ecological effects of armoring based on its purpose (e.g., to slow or stop water) and on wave energy at the structure. Using a suite of six ecological responses to shoreline structures (changes in habitat distribution, species assemblages, trophic structure, nutrient cycling, productivity, and connectivity), the model predicted that the ecological impacts of armoring will be larger for structures built to stop as opposed to slow water, and will increase with increasing energy. A literature review of the documented ecological effects of different types of shoreline structures (including living shorelines) across a range of environments (beaches, harbor shores, salt marshes, and mangroves) showed that $70 \%$ of the reported effects were significantly negative. However, the percentage of negative responses varied with the intended effect of the structure on water flow, with higher percentages observed for structures designed to stop water flow. Furthermore, the highest percentage of negative responses was reported for high-energy environments. These results suggest that the conceptual model is useful for predicting the relative impact of structures.

The use of living shorelines by fauna has only recently been investigated, and several studies have demonstrated improvements in diversity and abundance compared to traditional armored shorelines (Currin et al. 2010; Bilkovic and
Mitchell 2013; Balouskus and Targett 2016; Gittman et al. 2016a). However, further studies are needed to examine the ecological effects of living shorelines. Some hybrid armored features (e.g., marsh-sills) may provide improved habitat relative to traditional riprap, but only when they have a small footprint that minimally impacts the infauna displaced when structures are installed on the sediment surface (Bilkovic and Mitchell 2013). In this issue, Davenport et al. (2017) (Living shorelines support nearshore benthic communities in upper and lower Chesapeake Bay) monitored biological responses of shallow estuarine benthic communities to living shoreline construction for two case studies in Chesapeake Bay with before-after control-impact study designs. Communities of large $(>3 \mathrm{~mm}$ ) infauna adjacent to living shorelines at both study locations increased in biomass within 3 years of installation. Community assemblages and metrics (density, biomass, and species richness) showed similar trajectories at both living shoreline and fringing wetland control shorelines toward the end of the study period, suggesting that relatively mature living shorelines and fringing wetland shorelines support similar benthic infaunal communities. These results illustrate the need for long-term studies to understand the impacts of living shorelines on benthic communities.

\section{Effects of Shoreline Armoring and Land Use on Waterbirds}

Waterbirds, including waterfowl, shorebirds, marsh birds, seabirds, and wading birds, also respond to changes in ecological integrity associated with shoreline armoring and land use. Birds utilize a wide range of nearshore estuarine habitats including wetlands, intertidal flats, beaches, SAV, and shallow waters for foraging, breeding, nesting, roosting, migratory staging, and overwintering (Erwin 1996; Ma et al. 2010). In addition, waterbirds often occupy the highest trophic level in these ecosystems, so their abundance and diversity reflect conditions influencing lower trophic levels (Takekawa et al. 2006). Consequently, the loss or degradation of coastal habitats may have severe implications for waterbird populations (Erwin et al. 2011).

Waterbird communities can be negatively impacted by anthropogenic land use within the surrounding watershed (DeLuca et al. 2004; Shriver et al. 2004; DeLuca et al. 2008; Smith and Chow-Fraser 2010; Studds et al. 2012). Expansion of urban development and agricultural fields leads to fragmentation and loss of wetlands, which can reduce waterbird species diversity, overall abundance, and abundance of specialist species (Alsfeld et al. 2010; Celdrán and Aymerich 2010; Ludwig et al. 2010). Other stressors, such as nutrients and toxins in urban and suburban runoff, may influence waterbirds directly (Kushlan 1993) or indirectly, through reductions in prey abundance and diversity (Martínez Fernández et al. 2005; Bilkovic et al. 2006). The 
spread of invasive Phragmites may reduce habitat quality and function for some marsh waterbird species (Benoit and Askins 1999). These stressors may interact with habitat fragmentation and loss to further reduce waterbird community integrity.

At local scales, shoreline armoring may also negatively influence waterbird communities. Artificial structures lack the structural complexity and refuge function of natural shorelines, so they support different assemblages of epibiota and fish with reduced biodiversity relative to assemblages on natural shorelines (Seitz et al. 2006; Bulleri and Chapman 2010; Sobocinski et al. 2010; Strayer et al. 2012; Heerhartz et al. 2014, 2016). Consequently, armored shorelines offer reduced waterbird foraging habitat quality, which can lead to reductions in waterbird abundance and diversity (Dugan and Hubbard 2006; Dugan et al. 2008). In addition, shoreline armoring can lead to losses of foraging (Bulleri and Chapman 2010; Dugan et al. 2011) and roosting habitats (Erwin et al. 2006; Wilson et al. 2007; Clausen and Clausen 2014) by preventing landward migration of tidal wetlands and by deepening nearshore waters due to increased wave scour and reduced sediment inputs.

In this issue, Prosser et al. (2017) (Effects of local shoreline and subestuary watershed condition on waterbird community integrity: influences of geospatial scale and season in the Chesapeake Bay) examined waterbird community integrity during two seasons (late summer and late fall) in relation to shoreline armoring and land use characteristics in 21 Chesapeake Bay subestuaries. They considered three scales: (1) the shoreline scale characterized by seven shoreline types: bulkhead, riprap, developed, natural wetland, Phragmites-dominated wetland, sandy beach and forest; (2) the $500 \mathrm{~m}$ landscape scale surrounding the shoreline edge; and (3) the watershed scale. They incorporated waterbird survey data into an Index of Waterbird Community Integrity (IWCI) based on sensitivity to human disturbance to characterize the communities in each subestuary and season. Multivariate analysis showed that the local shoreline scale had the strongest influence on IWCI, and percent bulkhead and percent Phragmites along the shoreline were the strongest predictors of IWCI. In addition, low thresholds existed for Phragmites (5\%) and for bulkhead (8\%), beyond which IWCI declined. Their results indicate that local-scale shoreline armoring and the presence of invasive Phragmites have a negative effect on waterbirds using subestuarine systems.

\section{Management Approaches}

Effective management of estuarine and coastal ecosystems requires knowledge of community dynamics and ecological processes. However, estuarine science often is not effectively integrated into coastal management policies due to inherent obstacles between the scientific and management communities (e.g., institutional boundaries, governance issues, and the lag time between producing scientific results and developing management policies) (Leslie and McLeod 2007; ORAP 2013; Cvitanovic et al. 2015; Zedler 2017). In this issue, Turner and Jordan (2017) (Integrating management needs into a Mid-Atlantic shorelines research project) explored how the addition of management advisors to an estuarine science project influenced the direction of the science and the dissemination of results to interested stakeholders. They outlined the genesis and functions of the management advisory committee for a project dealing with the ecosystem effects of different shoreline and watershed types in the Mid-Atlantic region, and put the function of the committee in the context of previous reports that recommend the integration of science and management. This approach included (1) a well-targeted request for proposals; (2) a review process that included management input; (3) a process for selecting advisory committee members at the appropriate level in the agencies; (4) regular meetings between the advisory group and the science team through the duration of the project; and (5) active involvement of a program manager as the project liaison. Engagement of a management advisory group led to adaptations in scientific sampling and analyses to better reflect management interests, improved communication of results with managers, and formed a foundation for incorporation of the findings into regional management and initiatives.

\section{Summary}

The articles in this special issue advance the science and management of coastal systems in several ways. First, they quantify consistent negative impacts of agricultural and developed land and of shoreline armoring on nearshore water quality, estuarine habitats, and fauna. Second, they document the need for improved management to minimize the impacts of shoreline armoring, to conserve and restore coastal habitats, and to maintain valued ecosystem services in the face of changing land use and rising sea levels. Third, they highlight the need for more research on innovative practices, like living shorelines, which seek to stabilize shorelines while preserving habitat. Finally, they demonstrate the value of engaging environmental managers in planning and executing research programs. The studies in this issue focused primarily on changes in habitat and species distribution, leaving fundamental gaps in our knowledge of how shoreline armoring affects other ecological processes like nutrient cycling, productivity, and trophic interactions. Future studies could benefit by sampling shorelines before construction is initiated (using a before-after control-impact design) and by incorporating long-term monitoring, which is key to understanding overall ecosystem effects of anthropogenic alterations of the landscape. 
Acknowledgements The development of this thematic issue was possible through the hard work and dedication of all those who conducted and synthesized the research presented here. The authors are extremely grateful to Estuaries and Coasts co-Editors-in-Chief Wayne Gardner and Charles "Si" Simenstad for their support of this special issue. We especially thank Taylor Bowen for his assistance with managing the editorial aspects for all of the papers in the issue. The authors also would like to thank Donna Bilkovic, Iris Anderson and two anonymous reviewers for providing helpful comments to strengthen earlier versions of this manuscript. The use of trade, product, or firm names is for descriptive purposes only and does not imply endorsement by the U.S. Government. Photos used in Fig. 1a,b,c,e,f were provided courtesy of the Smithsonian Environmental Research Center. Symbols used in Fig. 2 and the photo used in Fig. 1d were provided courtesy of the Integration and Application Network, University of Maryland Center for Environmental Science (ian. umces.edu/symbols/).

Funding Funding for this paper was provided by the National Oceanic and Atmospheric Administration (NOAA) Center for Sponsored Coastal Ocean Research (CSCOR).

Open Access This article is distributed under the terms of the Creative Commons Attribution 4.0 International License (http://creativecommons. org/licences/by/4.0/), which permits use, duplication, adaptation, distribution and reproduction in any medium or format, as long as you give appropriate credit to the original author(s) and the source, provide a link to Creative Commons license and indicate if changes were made.

\section{References}

Ache, B.W., K.M. Crossett, P.A. Pacheco, J.E. Adkins, and P.C. Wiley. 2013. "The coast" is complicated: a model to consistently describe the nation's coastal population. Estuaries and Coasts 38: S151S155. https://doi.org/10.1007/s12237-013-9629-9.

Airoldi, L., and M.W. Beck. 2007. Loss, status and trends for coastal marine habitats of Europe. Oceanography and Marine Biology: An Annual Review 45: 345-405.

Alsfeld, A.J., J.L. Bowman, and A. Deller-Jacobs. 2010. The influence of landscape composition on the biotic community of constructed depressional wetlands. Restoration Ecology 18: 370-378. https:// doi.org/10.1111/j.1526-100X.2009.00628.x.

Balouskus, R.G., and T.E. Targett. 2016. Fish and blue crab density along a riprap-sill-hardened shoreline: comparisons with Spartina marsh and riprap. Transactions of the American Fisheries Society 145: 766-773.

Balouskus, R.G., and T.E. Targett. 2017. Impact of armored shorelines on shore-zone fish density in a mid-Atlantic, USA, estuary: modulation by hypoxia and temperature. Estuaries and Coasts https://doi.org/ 10.1007/s12237-017-0258-6.

Barbier, E.B., S.D. Hacker, C. Kennedy, E.W. Koch, A.C. Stier, and B.R. Silliman. 2011. The value of estuarine and coastal ecosystem services. Ecological Monographs 81: 169-193.

Bart, D., and J.M. Hartman. 2000. Environmental determinants of Phragmites australis expansion in a New Jersey salt marsh: an experimental approach. Oikos 89: 59-69.

Bart, D., D. Burdick, R. Chambers, and J.M. Hartman. 2006. Human facilitation of Phragmites Australis invasions in tidal marshes: a review and synthesis. Wetlands Ecology and Management 14: 5365. https://doi.org/10.1007/s11273-005-2566-z.

Batiuk, R., P. Bergstrom, W.M. Kemp, E.W. Koch, L. Murray, J.C. Stevenson, R. Bartleson, et al. 2000. Chesapeake bay submerged aquatic vegetation water quality and habitat based requirements and restoration targets: a second technical synthesis. Annapolis: U.S. Environmental Protection Agency Chesapeake Bay Program.

Beck, M.W., K.L. Heck Jr., K.W. Able, L. Daniel, D.B. Eggleston, B.M. Gillanders, B. Halpern, et al. 2001. The identification, conservation, and management of estuarine and marine nurseries for fish and invertebrates. Bioscience 51: 633-641.

Benoit, L.K., and R.A. Askins. 1999. Impact of the spread of Phragmites on the distribution of birds in Connecticut tidal marshes. Wetlands 19: 194-208.

Bilkovic, D.M., and M.M. Mitchell. 2013. Ecological tradeoffs of stabilized salt marshes as a shoreline protection strategy: Effects of artificial structures on macrobenthic assemblages. Ecological Engineering 61: 469-481. https://doi.org/10.1016/j.ecoleng.2013. 10.011

Bilkovic, D.M., and M.M. Roggero. 2008. Effects of coastal development on nearshore estuarine nekton communities. Marine Ecology Progress Series 358: 27-39. https://doi.org/10.3354/meps07279.

Bilkovic, D.M., M. Roggero, C.H. Hershner, and K.H. Havens. 2006. Influence of land use on macrobenthic communities in nearshore estuarine habitats. Estuaries and Coasts 29: 1185-1195. https:// doi.org/10.1007/BF02781819.

Bilkovic, D.M., M. Mitchell, P. Mason, and K. Duhring. 2016. The role of living shorelines as estuarine habitat conservation strategies. Coastal Management 44: 161-174. https://doi.org/10.1080/08920753.2016. 1160201.

Blankespoor, B., S. Dasgupta, and B. Laplante. 2014. Sea-level rise and coastal wetlands. Ambio 8: 996-1005.

Boesch, D.F., R.B. Brinsfield, and R.E. Magnien. 2001. Chesapeake Bay eutrophication: Scientific understanding, ecosystem restoration, and challenges for agriculture. Journal of Environmental Quality 30: 303-320.

Bologna, P.A.X., and K.L. Heck. 1999. Macrofaunal associations with seagrass epiphytes: relative importance of trophic and structural characteristics. Journal of Experimental Marine Biology and Ecology 242: 21-39.

Bourgeau-Chavez, L.L., K.P. Kowalski, M.L. Carlson, K.A. Scarbrough, R.B. Powell, C.N. Brooks, B. Huberty, et al. 2013. Mapping invasive Phragmites australis in the coastal Great Lakes with ALOS PALSAR satellite imagery for decision support. Journal of Great Lakes Research 39. Elsevier B.V.: 65-77. https://doi.org/10.1016/j. jglr.2012.11.001.

Bozek, C.M., and D.M. Burdick. 2005. Impacts of seawalls on saltmarsh plant communities in the Great Bay Estuary, New Hampshire USA. Wetlands Ecology and Management 13: 553-568. https://doi.org/ 10.1007/s11273-004-5543-z.

Brady, D.C., and T.E. Targett. 2013. Movement of juvenile weakfish Cynoscion regalis and spot Leiostomus xanthurus in relation to diel-cycling hypoxia in an estuarine tidal tributary. Marine Ecology Progress Series 491: 199-219. https://doi.org/10.3354/ meps10466.

Breitburg, D.L., D.W. Hondorp, L.A. Davias, and R.J. Diaz. 2009. Hypoxia, nitrogen, and fisheries: Integrating effects across local and global landscapes. Annual Review of Marine Science 1: 329 349. https://doi.org/10.1146/annurev.marine.010908.163754.

Bulleri, F. 2006. Is it time for urban ecology to include the marine realm? Trends in Ecology and Evolution 21: 658-659.

Bulleri, F., and M.G. Chapman. 2010. The introduction of coastal infrastructure as a driver of change in marine environments. Journal of Applied Ecology 47: 26-35. https://doi.org/10.1111/j.1365-2664. 2009.01751.x.

Celdrán, P.F., and F.R. Aymerich. 2010. Structure and distribution of the waterbird community in the Mar Menor Coastal Lagoon (SE Spain) and relationships with environmental gradients. Waterbirds 33: 479493. https://doi.org/10.1675/063.033.0407. 
Chambers, R.M., L.A. Meyerson, and K. Saltonstall. 1999. Expansion of Phragmites australis into tidal wetlands of North America. Aquatic Botany 64: 261-273.

Chapman, M.G. 2003. Paucity of mobile species on constructed seawalls: Effects of urbanization on biodiversity. Marine Ecology Progress Series 264: 21-29.

Chesapeake Bay Executive Council. 2003. Chesapeake Bay agreement. Strategy to accelerate the protection and restoration of submerged aquatic vegetation in Chesapeake Bay. Annapolis: U.S. E. P. A. Chesapeake Bay Program.

Chesapeake Bay Program. 2014. Chesapeake Bay Watershed Agreement. h t t p :// w w w. ches a p e k ebay.net/documents/ ChesapeakeBayWatershedAgreemenetFINAL.pdf.

Clark, K.L., G.M. Ruiz, and A.H. Hines. 2003. Diel variation in predator abundance, predation risk and prey distribution in shallow-water estuarine habitats. Journal of Experimental Marine Biology and Ecology 287: 37-55.

Clausen, K.K., and P. Clausen. 2014. Forecasting future drowning of coastal waterbird habitats reveals a major conservation concern. Biological Conservation 171. Elsevier Ltd: 177-185. https://doi. org/10.1016/j.biocon.2014.01.033.

Comin, F.A., J.A. Romero, V. Astorga, and C. García. 1997. Nitrogen removal and cycling in restored wetlands used as filters of nutrients for agricultural runoff. Water Science and Technology 35: 255-261.

Costanza, R., R. Arge, R. De Groot, S. Farber, M. Grasso, B. Hannon, K. Limburg, et al. 1997. The value of the world's ecosystem services and natural capital. Nature 387: 253-260.

Crum, K.P., R.G. Balouskus, and T.E. Targett. 2017. Growth and movements of mummichogs (Fundulus heteroclitus) along armored and vegetated estuarine shorelines. Estuaries and Coasts https://doi.org/ 10.1007/s12237-017-0299-x.

Currin, C.A., W.S. Chappell, and A. Deaton. 2010. Developing alternative shoreline armoring strategies: the living shoreline approach in North Carolina. Shipman, H., Dethier, M.N., Gelfenbaum, G., Fresh, K.L., and Dinicola, R.S., eds., Puget Sound Shorelines and the Impacts of Armoring-Proceedings of a State of the Science Workshop, May 2009.

Currin, C., J. Davis, L.C. Baron, A. Malhotra, and M. Fonseca. 2015. Shoreline change in the New River Estuary, North Carolina: rates and consequences. Journal of Coastal Research 31: 1069-1077. https://doi.org/10.2112/JCOASTRES-D-14-00127.1.

Cvitanovic, C., A.J. Hobday, L. Van Kerkhoff, S.K. Wilson, K. Dobbs, and N.M. Marshall. 2015. Improving knowledge exchange among scientists and decision-makers to facilitate the adaptive governance of marine resources: a review of knowledge and research needs. Ocean and Coastal Management 112. Elsevier Ltd: 25-35. https:// doi.org/10.1016/j.ocecoaman.2015.05.002.

Dahl, T.W. 2011. Status and trends of wetlands in the conterminous United States 2004 to 2009. Washington, DC: U.S. Department of the Interior, Fish and Wildlife Service.

Dauer, D.M., S.B. Weisberg, and J.A. Ranasinghe. 2000. Relationships between benthic community condition, water quality, sediment quality, nutrient loads, and land use patterns in Chesapeake Bay. Estuaries 23: 80-96.

Davenport, T.M., R.D. Seitz, K.E. Knick, and N. Jackson. 2017. Living shorelines support near-shore benthic communities in upper and lower Chesapeake Bay. Estuaries and Coasts. https://doi.org/10. 1007/s12237-017-0361-8

Davis, J.L.D., R.L. Takacs, and R. Schnabel. 2008. Evaluating ecological impacts of living shorelines and shoreline habitat elements: an example from the upper western Chesapeake Bay. In Management policy, science and engineering of nonstructural erosion control in the Chesapeake Bay: Proceedings of the 2006 Living Shoreline Summit. CRC Publ. 08-164, ed. S.Y. Erdle, J.L.D. Davis, and K.D. Sellner, 55-61. Boca Raton: CRC Press.
Davis, J.L., C.A. Currin, C.O. Brien, C. Raffenburg, and A. Davis. 2015. Living shorelines: coastal resilience with a blue carbon benefit. PLoS One 10: e0142595. https://doi.org/10.1371/journal.pone. 0142595.

de Boer, W.F. 2007. Seagrass-sediment interactions, positive feedbacks and critical thresholds for occurrence: a review. Hydrobiologia 544: 5-24. https://doi.org/10.1007/s10750-007-0780-9.

de Jonge, V.N., M. Elliott, and E. Orive. 2002. Causes, historical development, effects and future challenges of a common environmental problem: eutrophication. In Nutrients and eutrophication in estuaries and coastal waters, ed. Emma Orive, Matthew Elliot, and Victor N. de Jonge, 1-19. Netherlands: Springer.

Deegan, L.A., D.S. Johnson, R.S. Warren, B.J. Peterson, J.W. Fleeger, S. Fagherazzi, and W.M. Wollheim. 2012. Coastal eutrophication as a driver of salt marsh loss. Nature 490. 388-392. https://doi.org/10. 1038/nature11533.

DeLuca, W.V., C.E. Studds, L.L. Rockwood, and P.P. Marra. 2004. Influence of land use on the integrity of marsh bird communities of Chesapeake Bay, USA. Wetlands 24: 837-847. https://doi.org/10. 1672/0277-5212(2004)024[0837:IOLUOT]2.0.CO;2.

DeLuca, W.V., C.E. Studds, R.S. King, and P.P. Marra. 2008. Coastal urbanization and the integrity of estuarine waterbird communities: threshold responses and the importance of scale. Biological Conservation 141. Elsevier Ltd: 2669-2678. https://doi.org/10. 1016/j.biocon.2008.07.023.

Diaz, R.J., and R. Rosenberg. 2008. Spreading dead zones and consequences for marine ecosystems. Science 321: 926-929. https://doi. org/10.1126/science.1156401.

Dibble, K.L., and L.A. Meyerson. 2014. The effects of plant invasion and ecosystem restoration on energy flow through salt marsh food webs. Estuaries and Coasts 37: 339-353. https://doi.org/10.1007/s12237013-9673-5.

Dittel, A.I., A.H. Hines, G.M. Ruiz, and K.K. Ruffin. 1995. Effects of shallow water refuge on behavior and density-dependent mortality of juvenile blue crabs in Chesapeake Bay. Bulletin of Marine Science 57: 902-916.

Domingo, J.L., and A. Bocio. 2007. Levels of PCDD/PCDFs and PCBs in edible marine species and human intake: A literature review. Environmental International 33: 397-405. https://doi.org/10.1016/ j.envint.2006.12.004.

Doney, S.C. 2010. The growing human footprint on coastal and openocean biogeochemistry. Science 328: 1512-1516. https://doi.org/10. 1126/science. 1185198.

Doody, J.P. 2004. "Coastal squeeze"-An historical perspective. Journal of Coastal Conservation 10: 129-138.

Drake, K., H. Halifax, S.C. Adamowicz, and C. Craft. 2015. Carbon sequestration in tidal salt marshes of the northeast United States. Environmental Management 56: 998-1008.

Duarte, C.M. 2005. Submerged aquatic vegetation in relation to different nutrient regimes. Ophelia 41: 87-112.

Dugan, J.E., and D.M. Hubbard. 2006. Ecological responses to coastal armoring on exposed sandy beaches. Shore and Beach 74: 10-16. https://doi.org/10.1111/j.1439-0485.2008.00231.x.

Dugan, J.E., D.M. Hubbard, I.F. Rodil, D.L. Revell, and S. Schroeter. 2008. Ecological effects of coastal armoring on sandy beaches. Marine Ecology 29: 160-170.

Dugan, J.E., L. Airoldi, M.G. Chapman, S.J. Walker, and T. Schlacher. 2011. Estuarine and coastal structures: environmental effects, a focus on shore and nearshore structures. Treatise on Estuarine and Coastal Science 8: Elsevier Inc. https://doi.org/10.1016/B978-012-374711-2.00802-0.

Dugan, J., M. Alber, C. Alexander, J. Byers, K. Emery, A.-L. Gehman, N. McLenaghan, and S. Sojka. 2017. Generalizing ecological effects of shoreline armoring across soft sediment environments. Estuaries and Coasts. https://doi.org/10.1007/s12237-017-0254-x 
Duhring, K. 2008. Overview of living shoreline design options for erosion protection on tidal shorelines. In Management policy, science and engineering of nonstructural erosion control in the Chesapeake Bay: Proceedings of the 2006 Living Shoreline Summit. CRC Publ. 08-164, ed. S.Y. Erdle, J.L.D. Davis, and K.G. Sellner, 13-18. Boca Raton: CRC Press.

Eby, L.A., and L.B. Crowder. 2004. Effects of hypoxic disturbances on an estuarine nekton assemblage across multiple scales. Estuaries and Coasts 27: 342-351.

Erwin, R.M. 1996. Dependence of waterbirds and shorebirds on shallowwater habitats in the mid-Atlantic coastal region: an ecological profile and management recommendations. Estuaries 19: 213-219. https://doi.org/10.2307/1352226.

Erwin, R.M., G.M. Sanders, D.J. Prosser, and D.R. Cahoon. 2006. High tides and rising seas: potential effects on estuarine waterbirds. Studies in Avian Biology: 214-228.

Erwin, R.M., D.F. Brinker, B.D. Watts, G.R. Costanzo, and D.D. Morton. 2011. Islands at bay: rising seas, eroding islands, and waterbird habitat loss in Chesapeake Bay (USA). Journal of Coastal Conservation 15: 51-60. https://doi.org/10.1007/s11852-0100119-y.

Findlay, S.E.G., D.L. Strayer, S.D. Smith, and N. Curri. 2014. Magnitude and patterns of change in submerged aquatic vegetation of the tidal freshwater Hudson River. Estuaries and Coasts 37: 1233-1242. https://doi.org/10.1007/s12237-013-9758-1.

Fletcher, C.H., R.A. Mullane, and B.M. Richmond. 1997. Beach loss along armored shorelines on Oahu, Hawaiian islands. Journal of Coastal Research 13: 209-215.

Gabriel, A.O., and L.R. Bodensteiner. 2012. Impacts of riprap on wetland shorelines, Upper Winnebago pool lakes, Wisconsin. Wetlands 32: 105-117. https://doi.org/10.1007/s13157-011-0251-y.

Gehman, A.-L., N. McLenaghan, J. Byers, C. Alexander, S. Pennings, and M. Alber. 2017. Effects of small-scale armoring and residential development on the salt marsh-upland ecotone. Estuaries and Coasts. https://doi.org/10.1007/s12237-017-0300-8

Gillanders, B.M. 2006. Seagrasses, fish, and fisheries. In Seagrasses: biology, ecology and conservation, ed. Anthony Larkum, Robert J. Orth, and Carlos Duarte, 503-535. Dordrecht: Springer Netherlands. https://doi.org/10.1007/978-1-4020-2983-7 21.

Gittman, R.K., A.M. Popowich, J.F. Bruno, and C.H. Peterson. 2014. Marshes with and without sills protect estuarine shorelines from erosion better than bulkheads during a category 1 hurricane. Ocean and Coastal Management 102: 94-102. https://doi.org/10. 1016/j.ocecoaman.2014.09.016.

Gittman, R.K., F.J. Fodrie, A.M. Popowich, D.A. Keller, J.F. Bruno, C.A. Currin, C.H. Peterson, and M.F. Piehler. 2015. Engineering away our natural defenses: an analysis of shoreline hardening in the US. Frontiers in Ecology and the Environment 13: 301-307. https://doi. org/10.1890/150065.

Gittman, R.K., C.H. Peterson, C.A. Currin, F. Joel Fodrie, M.F. Piehler, and J.F. Bruno. 2016a. Living shorelines can enhance the nursery role of threatened estuarine habitats. Ecological Applications 26: 249-263. https://doi.org/10.1890/14-0716.1/suppinfo.

Gittman, R.K., S.B. Scyphers, C.S. Smith, I.P. Neylan, and J.H. Grabowski. 2016b. Ecological consequences of shoreline hardening: a meta-analysis. Bioscience 66: 763-773. https://doi.org/10. 1093/biosci/biw091.

Glasgow, H.B., Jr., J.M. Burkholder, D.E. Schmechel, P.A. Tester, and P.A. Rublee. 1995. Insidious effects of a toxic estuarine dinoflagellate on fish survival and human health. Journal of Toxicology and Environmental Health 45: 501-522.

Greening, H., and A. Janicki. 2006. Toward reversal of eutrophic conditions in a subtropical estuary: Water quality and seagrass response to nitrogen loading reductions in Tampa Bay, Florida, USA.
Environmental Management 38: 163-178. https://doi.org/10.1007/ s00267-005-0079-4.

Gregg, T., F.G. Prahl, and B.R.T. Simoneit. 2015. Suspended particulate matter transport of polycyclic aromatic hydrocarbons in the lower Columbia River and its estuary. Limnology and Oceanography 60: 1935-1949.

Griggs, G.B. 2005. The impacts of coastal armoring. Shore \& Beach 73: $13-22$.

Gruber, R.K., and W.M. Kemp. 2010. Feedback effects in a coastal canopy-forming submersed plant bed. Limnology and Oceanography 55: 2285-2298. https://doi.org/10.4319/lo.2010.55. 6.2285 .

Hall, M.J., and O.H. Pilkey. 1991. Effects of hard stabilization on dry beach width for New Jersey. Journal of Coastal Research 7: 771785 .

Havens, K.J., H. Berquist, and W. Priest III. 2003. Common red grass, Phragmites australis, expansion into constructed wetlands: are we mortgaging our wetland future? Estuaries 26: 417-422.

Hazelton, E.L.G., T.J. Mozdzer, D.M. Burdick, K.M. Kettenring, and D.F. Whigham. 2014. Phragmites australis management in the United States: 40 years of methods and outcomes. AoB Plants 6: plu001. https://doi.org/10.1093/aobpla/plu001.

Hazelton, E.L.G., K.M. Kettenring, R. Downard, M.K. McCormick, and D.F. Whigham. 2017. Spatial and temporal variation in brackish wetland seedbanks: implications for wetland restoration following Phragmites control. Estuaries and Coasts. https://doi.org/10.1007/ s12237-017-0289-Z

Heck, K.L., Jr., T.J.B. Carruthers, C.M. Duarte, A. Randall, G. Kendrick, R.J. Orth, and S.W. Williams. 2008. Trophic transfers from seagrass meadows subsidize diverse marine and terrestrial consumers. Ecosystems 11: 1198-1210. https://doi.org/10.1007/s10021-0089155-y.

Heerhartz, S.M., M.N. Dethier, J.D. Toft, J.R. Cordell, and A.S. Ogston. 2014. Effects of shoreline armoring on beach wrack subsidies to the nearshore ecotone in an estuarine fjord. Estuaries and Coasts 37: 1256-1268. https://doi.org/10.1007/s12237-013-9754-5.

Heerhartz, S.M., J.D. Toft, J.R. Cordell, M.N. Dethier, and A.S. Ogston. 2016. Shoreline armoring in an estuary constrains wrack-associated invertebrate communities. Estuaries and Coasts 39: 171-188. https://doi.org/10.1007/s12237-015-9983-x.

Hemminga, M.A., and C.M. Duarte. 2000. Seagrass ecology. Cambridge: Cambridge University Press.

Hobbs, R.J. 2000. Land-use changes and invasion. In Invasive species in a changing world, ed. H.A. Mooney and R.J. Hobbs, 55-64. Washington, D.C.: Island Press.

Holland, A.F., D.M. Sanger, C.P. Gawle, S.B. Lerberg, M. Sexto, G.H.M. Riekerk, L.E. Zimmerman, and G.I. Scott. 2004. Linkages between tidal creek ecosystems and the landscape and demographic attributes of their watersheds. Journal of Experimental Marine Biology and Ecology 298: 151-178. https://doi.org/10.1016/S0022-0981(03) 00357-5.

Howarth, R., F. Chan, D.J. Conley, J. Garnier, S.C. Doney, R. Marino, and G. Billen. 2011. Coupled biogeochemical cycles: eutrophication and hypoxia in temperate estuaries and coastal marine ecosystems. Frontiers in Ecology and the Environment 9: 18-26. https://doi.org/ 10.1890/100008.

Howes, B.L., P.K. Weiskel, D.D. Goehringer, and J.M. Teal. 1996. Interception of freshwater and nitrogen transport from uplands to coastal waters: the role of saltmarshes. In Estuarine shores: hydrological, geomorphological, and ecological interactions, ed. K.F. Nordstrom and Charles T. Roman, 287-310. Sussex: John Wiley and Sons, Ltd.

Jennings, G.D., W.D. Harman, J.C. Ascough, and D.C. Flanagan. 2001. Measurement and stabilization of streambank erosion in North Carolina. In Soil erosion research for the 21 st century. 
Proceedings of the International Symposium, Honolulu, Hawaii, USA, 3-5 January, 2001, 537-540. American Society of Agricultural Engineers.

Jodoin, Y., C. Lavoie, P. Villeneuve, M. Theriault, J. Beaulieu, and F. Belzile. 2008. Highways as corridors and habitats for the invasive common reed Phragmites australis in Quebec, Canada. Journal of Applied Ecology 45: 459-466. https://doi.org/10.1111/j.1365-2664. 2007.01362.x.

Jones, K.M.M., and K.W. Able. 2015. Abundance and diet of predatory fishes in Phragmites, treated Phragmites, and natural Spartina marshes in Delaware Bay. Estuaries and Coasts 38: 1350-1364. https://doi.org/10.1007/s12237-014-9883-5.

Jones, K.M.M., P.E. Mcgrath, and K.W. Able. 2014. White perch Morone americana (Gmelin, 1789) habitat choice and movements: Comparisons between Phragmites-invaded and Spartina reference marsh creeks based on acoustic telemetry. Journal of Experimental Marine Biology and Ecology 455: 14-21. https://doi.org/10.1016/j. jembe.2014.02.011.

Jordan, T.E., D.L. Correll, and D.E. Weller. 1997. Effects of agriculture on discharges of nutrients from coastal plain watershed of Chesapeake Bay. Journal of Environmental Quality 26: 836-848. https://doi.org/10.2134/jeq1997.00472425002600030034x.

Jordan, T.E., D.E. Weller, and D.L. Correll. 2003. Sources of nutrient inputs to the Patuxent River estuary. Estuaries 26: 226-243. https://doi.org/10.1007/BF02695964

Jordan, T.E., D.E. Weller, and C.E. Pelc. 2017. Effects of watershed land use on nutrients and chlorophyll in mid-Atlantic coastal bays and subestuaries of the Chesapeake Bay. Estuaries and Coasts. https:// doi.org/10.1007/s12237-017-0303-5

Kemp, W.M., R. Bartleson, P. Bergstrom, V. Carter, C.L. Gallegos, W. Hunley, L. Karrh, et al. 2004. Habitat requirements for submerged aquatic vegetation in Chesapeake Bay: water quality, light regime, and physical-chemical factors. Estuaries 27: 363-377.

Kemp, W.M., W.R. Boynton, J.E. Adolf, D.F. Boesch, W.C. Boicourt, G. Brush, J.C. Cornwell, et al. 2005. Eutrophication of Chesapeake Bay: historical trends and ecological interactions. Marine Ecology Progress Series 303: 1-29. https://doi.org/10.3354/meps303001.

Kettenring, K.M., M.K. Mccormick, H.M. Baron, and D.F. Whigham. 2011. Mechanisms of Phragmites australis invasion: feedbacks among genetic diversity, nutrients, and sexual reproduction. Journal of Applied Ecology 48: 1305-1313. https://doi.org/10. 1111/j.1365-2664.2011.02024.x.

Kettenring, K.M., D.F. Whigham, E.L.G. Hazelton, S.K. Gallagher, and H.M. Weiner. 2015. Biotic resistance, disturbance, and mode of colonization impact the invasion of a widespread, introduced wetland grass. Ecological Applications 25: 466-480.

King, R.S., J.R. Beaman, D.F. Whigham, A.H. Hines, M.E. Baker, and D.E. Weller. 2004. Watershed land use is strongly linked to PCBs in white perch in Chesapeake Bay subestuaries. Environmental Science \& Technology 38: 6546-6552. https://doi.org/10.1021/ es $049059 \mathrm{~m}$

King, R.S., A.H. Hines, F.D. Craige, and S. Grap. 2005. Regional, watershed and local correlates of blue crab and bivalve abundances in subestuaries of Chesapeake Bay, USA. Journal of Experimental Marine Biology and Ecology 319: 101-116. https://doi.org/10. 1016/j.jembe.2004.05.022.

King, R.S., W.V. Deluca, D.F. Whigham, and P.P. Marra. 2007. Threshold effects of coastal urbanization on Phragmites australis (common reed) abundance and foliar nitrogen in Chesapeake Bay. Estuaries and Coasts 30: 469-481. https://doi.org/10.1007/BF02819393.

Kirwan, M.L., and J.P. Megonigal. 2013. Tidal wetland stability in the face of human impacts and sea-level rise. Nature 504: 3-10. https:// doi.org/10.1038/nature12856.

Kirwan, M.L., D.C. Walters, W.G. Reay, and J.A. Carr. 2016. Sea level driven marsh expansion in a coupled model of marsh erosion and migration. Geophysical Research Letters 43: 4366-4373. https:// doi.org/10.1002/2016GL068507.Received.

Kiviat, E. 2013. Ecosystem services of Phragmites in North America with emphasis on habitat functions. AoB Plants 5: plt008. https:// doi.org/10.1093/aobpla/plt008.

Kornis, M.S., D.M. Bilkovic, L.A. Davias, S. Giordano, and D.L. Breitburg. 2017. Shoreline hardening affects nekton biomass, size structure and taxonomic diversity in nearshore waters, with responses mediated by functional species groups. Estuaries and Coasts. https://doi.org/10.1007/s12237-017-0214-5

Kowalski, K.P., C. Bacon, W. Bickford, H. Braun, K. Clay, M. Leduclapierre, E. Lillard, et al. 2015. Advancing the science of microbial symbiosis to support invasive species management: a case study on Phragmites in the Great Lakes. Frontiers in Microbiology 6: 95. https://doi.org/10.3389/fmicb.2015.00095.

Kulmatiski, A., K.H. Beard, L.A. Meyerson, J.R. Gibson, and K.E. Mock. 2010. Nonnative Phragmites australis invasion into Utah wetlands. Western North American Naturalist 70: 541-552.

Kushlan, J.A. 1993. Colonial waterbirds as bioindicators of environmental change. Colonial Waterbirds 16: 223-251.

La Peyre, M.K., A.T. Humphries, S.M. Casas, and J.F. La Peyre. 2014. Temporal variation in development of ecosystem services from oyster reef restoration. Ecological Engineering 63. Elsevier B.V.: 34 44. https://doi.org/10.1016/j.ecoleng.2013.12.001.

Landry, J.B., and R.R. Golden. 2017. In situ effects of shoreline type and watershed land use on submerged aquatic vegetation habitat quality in the Chesapeake and Mid-Atlantic Coastal Bays. Estuaries and Coasts. https://doi.org/10.1007/s12237-017-0316-0

Langley, J.A., K.L. Mckee, D.R. Cahoon, J.A. Cherry, and J.P. Megonigal. 2009. Elevated $\mathrm{CO}_{2}$ stimulates marsh elevation gain, counterbalancing sea-level rise. Proceedings of the National Academy of Sciences of the United States of America 106: 61826186.

Larson, D.L., S. Galatowitsch, and J.L. Larson. 2011. Native and European haplotypes of Phragmites australis (Common Reed) on the Central Platte River, Nebraska. Great Plains Research 21: 175180.

Lawless, A.S., and R.D. Seitz. 2014. Effects of shoreline stabilization and environmental variables on benthic infaunal communities in the Lynnhaven River System of Chesapeake Bay. Journal of Experimental Marine Biology and Ecology 457. Elsevier B.V.: 41-50. https://doi.org/10.1016/j.jembe.2014.03.010.

Leblanc, M., S. De Blois, and C. Lavoie. 2010. The invasion of large lake by the Eurasian genotype of common reed: the influence of roads and residential construction. Journal of Great Lakes Research 36: 554-560. https://doi.org/10.1016/j.jglr.2010.06.001.

Lefcheck, J.S., D.J. Wilcox, R.R. Murphy, S.R. Marion, and R.J. Orth. 2017. Multiple stressors threaten the imperiled coastal foundation species eelgrass (Zostera marina) in Chesapeake Bay, USA. Global Change Biology 23: 3474-3483. https://doi. org/10.1111/gcb.13623.

Lelong, B., C. Lavoie, Y. Jodoin, and F. Belzile. 2007. Expansion pathways of the exotic common reed (Phragmites australis): a historical and genetic analysis. Diversity and Distributions 13: 430-437. https://doi.org/10.1111/j.1472-4642.2007.00351.x.

Leslie, H.M., and K.L. McLeod. 2007. Confronting the challenges of implementing marine ecosystem-based management. Frontiers in Ecology and the Environment 5: 540-548. https://doi.org/10.1890/ 060093.

Li, X., D.E. Weller, C.L. Gallegos, T.E. Jordan, and H.-C. Kim. 2007. Effects of watershed and estuarine characteristics on the abundance of submerged aquatic vegetation in Chesapeake Bay subestuaries. Estuaries and Coasts 30: 840-854. https://doi.org/10.1007/ BF02841338.

Lovall, C.D., R.D. Seitz, and K.E. Knick. 2017. Direct and indirect impacts of shoreline development on shallow-water benthic communi- 
ties in a depauperate estuarine system. Bulletin of Marine Science 93: 715-741.

Ludwig, D.F., J. Iannuzzi, T.J. Iannuzzi, and J.K. Shisler. 2010. Spatial and temporal habitat use patterns by water birds in an urban estuarine ecosystem: implications for ecosystem management and restoration. Human and Ecological Risk Assessment 16: 163-184. https:// doi.org/10.1080/10807030903459106.

Ma, Z., Y. Cai, B. Li, and J. Chen. 2010. Managing wetland habitats for waterbirds: an international perspective. Wetlands 30: 15-27. https:// doi.org/10.1007/s13157-009-0001-6.

Madsen, J.D., P.A. Chambers, W.F. James, E.W. Koch, and D.F. Westlake. 2001. The interaction between water movement, sediment dynamics and submersed macrophytes. Hydrobiologia 44: 71-84.

Martínez Fernández, J., M.A. Esteve Selma, F.R. Aymerich, M.T. Pardo Sáez, and M.F. Carreño Fructuoso. 2005. Aquatic birds as bioindicators of trophic changes and ecosystem deterioration in the Mar Menor lagoon (SE Spain). Hydrobiologia 550: 221-235. https://doi.org/10.1007/s10750-005-4382-0.

Miles, J.R., P.E. Russell, and D.A. Huntley. 2001. Field measurements of sediment dynamics in front of a seawall. Journal of Coastal Research 17: 195-206. https://doi.org/10.2307/4300163.

Miller, D.C., R.J. Geider, and H.L. MacIntyre. 1996. Microphytobenthos: the ecological role of the "secret garden" of unvegetated, shallowwater marine habitats. II. Role in sediment stability and shallowwater food webs. Estuaries 19: 202-212.

Moore, K.A. 2004. Influence of seagrasses on water quality in shallow regions of the lower Chesapeake Bay. Journal of Coastal Research 45: $162-178$.

Moore, K.A., and J.C. Jarvis. 2008. Environmental factors affecting recent summertime eelgrass diebacks in the lower Chesapeake Bay: implications for long-term persistence. Journal of Coastal Research 55: 135-147. https://doi.org/10.2112/SI55-014.acteristics.

Moore, K.A., R.L. Wetzel, and R.J. Orth. 1997. Seasonal pulses of turbidity and their relations to eelgrass (Zostera marina $L$ ) survival in an estuary. Journal of Experimental Marine Biology and Ecology 215: 115-134.

Morley, S.A., J.D. Toft, and K.M. Hanson. 2012. Ecological effects of shoreline armoring on intertidal habitats of a Puget sound urban estuary. Estuaries and Coasts 35: 774-784. https://doi.org/10. 1007/s12237-012-9481-3.

Nixon, S.W. 1980. Between coastal marshes and coastal water-a review of twenty years of speculation and research in the role of salt marshes in estuarine productivity and water chemistry. In Wetland processes with emphasis on modeling, ed. P. Hamilton and K.B. MacDonald, 437-525. New York: Plenum Press.

Nixon, S.W. 1995. Coastal marine eutrophication: a definition, social causes, and future consequences. Ophelia 41: 199-219.

Nordstrom, K.F. 2014. Living with shore protection structures : A review. Estuarine, Coastal and Shelf Science 150. Elsevier Ltd: 11-23. https://doi.org/10.1016/j.ecss.2013.11.003.

NRC [National Resource Council]. 2007. Mitigating shoreline erosion along sheltered coasts. Ocean study board, National Research Council. Washington, DC: National Academies Press.

ORAP, [Ocean Research Advisory Panel]. 2013. Implementing ecosystem-based management: a report to the National Ocean Council. Arlington.

Orth, R.J., and K.A. Moore. 1983. An unprecedented decline in submerged aquatic vegetation. Science 222: 51-54.

Orth, R.J., T.J.B. Carruthers, W.C. Dennison, C.M. Duarte, J.W. Fourqurean, K.L. Heck, A.R. Hughes, et al. 2006. A global crisis for seagrass ecosystems. Bioscience 56: 987-996. https://doi.org/10. 1641/0006-3568(2006)56[987:AGCFSE]2.0.CO;2.

Orth, R.J., M.R. Williams, S.R. Marion, D.J. Wilcox, T.J.B. Carruthers, K.A. Moore, W.M. Kemp, et al. 2010. Long-term trends in submersed aquatic vegetation (SAV) in Chesapeake Bay, USA, related to water quality. Estuaries and Coasts 33: 1144-1163. https://doi. org/10.1007/s12237-010-9311-4.

Orth, R.J., W.C. Dennison, J.S. Lefcheck, C. Gurbisz, M. Hannam, J. Keisman, J.B. Landry, et al. 2017. Submersed aquatic vegetation in Chesapeake Bay: sentinel species in a changing world. Bioscience 67: 698-712.

Paerl, H.W., N.S. Hall, B.L. Peierls, and K.L. Rossignol. 2014. Evolving paradigms and challenges in estuarine and coastal eutrophication dynamics in a culturally and climatically stressed world. Estuaries and Coasts 37: 243-258. https://doi.org/10.1007/s12237-014-9773$\mathrm{x}$.

Parikh, J., and H. Datye. 2003. Sustainable management of wetlands: biodiversity and beyond. India: Sage Publications.

Pastore, M.A., J.P. Megonigal, and J.A. Langley. 2017. Elevated $\mathrm{CO}_{2}$ and nitrogen addition accelerate net carbon gain in a brackish marsh. Biogeochemistry 133: 73-87.

Patrick, C.J., and D.E. Weller. 2015. Interannual variation in submerged aquatic vegetation and its relationship to water quality in subestuaries of Chesapeake Bay. Marine Ecology Progress Series 537: 121-135. https://doi.org/10.3354/meps11412.

Patrick, C.J., D.E. Weller, X. Li, and M. Ryder. 2014. Effects of shoreline alteration and other stressors on submerged aquatic vegetation in subestuaries of Chesapeake Bay and the Mid-Atlantic coastal bays. Estuaries and Coasts 37: 1516-1531. https://doi.org/10.1007/ s12237-014-9768-7.

Patrick, C.J., D.E. Weller, and M. Ryder. 2016. The relationship between shoreline armoring and adjacent submerged aquatic vegetation in Chesapeake Bay and nearby Atlantic coastal bays. Estuaries and Coasts 39: 158-170. https://doi.org/10.1007/ s12237-015-9970-2.

Patrick, C.J., D.E. Weller, R.J. Orth, D.J. Wilcox, and M.P. Hannam. 2017. Land use and salinity drive changes in SAV abundance and community composition. Estuaries and Coasts. https://doi.org/10. 1007/s12237-017-0250-1

Peterson, M.S., and M.R. Lowe. 2009. Implications of cumulative impacts to estuarine and marine habitat quality for fish and invertebrate resources. Reviews in Fisheries Science 17: 505-523.

Philipp, K.R., and R.T. Field. 2005. Phragmites australis expansion in Delaware Bay salt marshes. Ecological Engineering 25: 275-291. https://doi.org/10.1016/j.ecoleng.2005.04.008.

Pilkey, O.H., and H.L. Wright. 1988. Seawalls versus beaches. Journal of Coastal Research: 41-64.

Plant, N.G., and G.B. Griggs. 1992. Interactions between nearshore processes and beach morphology near a seawall. Journal of Coastal Research 8: 183-200.

Pontee, N. 2013. Defining coastal squeeze: a discussion. Ocean and Coastal Management 84: 1-4. https://doi.org/10.1016/j. ocecoaman.2013.07.010.

Prosser, D.J., J.L. Nagel, S. Howlin, P.R. Marban, D.D. Day, and R.M. Erwin. 2017. Effects of local shoreline and subestuary watershed condition on waterbird community integrity: influences of geospatial scale and season in the Chesapeake Bay region. Estuaries and Coasts. https://doi.org/10.1007/s12237-017-0288-0

Rabalais, N.N., and R.E. Turner. 2001. Coastal hypoxia: consequences for living resources and ecosystems. Coastal and estuarine studies, volume 58. Washington, DC: American Geophysical Union.

Roberts, S. 2008. The National Academies report on mitigating shore erosion along sheltered coasts. In Management policy, science and engineering of nonstructural erosion control in the Chesapeake Bay: Proceedings of the 2006 living shoreline summit. CRC Publ. 08-164, ed. S.Y. Erdle, J.L.D. Davis, and K.G. Sellner, 3-6. Boca Raton: CRC Press.

Rooth, J.E., and J.C. Stevenson. 2000. Sediment deposition patterns in Phragmites australis communities: implications for coastal areas threatened by rising sea-level. Wetlands Ecology and Management 8: $173-183$. 
Ruiz, G.M., A.H. Hines, and H. Martin. 1993. Shallow water as a refuge habitat for fish and crustaceans in non-vegetated estuaries: an example from Chesapeake Bay. Marine Ecology Progress Series 99: 116.

Sanford, L.P., and J. Gao. 2017. Influences of wave climate and sea level on shoreline erosion rates in the Maryland Chesapeake Bay. Estuaries and Coasts. https://doi.org/10.1007/s12237-017-0257-7

Scavia, D., and S.B. Bricker. 2006. Coastal eutrophication assessment in the United States. Biogeochemistry 79: 187-208. https://doi.org/10. 1007/s10533-006-9011-0.

Sciance, M.B., C.J. Patrick, D.E. Weller, M.N. Williams, M.K. McCormick, and E.L.G. Hazelton. 2016. Local and regional disturbances associated with the invasion of Chesapeake Bay marshes by the common reed Phragmites australis. Biological Invasions 18: 2661-2677. https://doi.org/10.1007/s10530-016-1136-z.

Scyphers, S.B., T.C. Gouhier, J.H. Grabowski, M.W. Beck, J. Mareska, and S.P. Powers. 2015. Natural shorelines promote the stability of fish communities in an urbanized coastal system. PLoS One 10: 112. https://doi.org/10.1371/journal.pone.0118580.

Seitz, R.D., and A.S. Lawless. 2008. Landscape-level impacts of shoreline development upon Chesapeake Bay benthos and their predators. In Management policy, science and engineering of nonstructural erosion control in the Chesapeake Bay: Proceedings of the 2006 Living Shoreline Summit. CRC Publ. 08-164, ed. S.Y. Erdle, J.L.D. Davis, and K.G. Sellner, 63-70. Edgewater: Chesapeake Research Consortium.

Seitz, R.D., R.N. Lipcius, N.H. Olmstead, M.S. Seebo, and D.M. Lambert. 2006. Influence of shallow-water habitats and shoreline development on abundance, biomass, and diversity of benthic prey and predators in Chesapeake Bay. Marine Ecology Progress Series 326: 11-27. https://doi.org/10.3354/meps326011.

Seitz, R.D., H. Wennhage, U. Bergström, R.N. Lipcius, and T. Ysebaert. 2014. Ecological value of coastal habitats for commercially and ecologically important species. ICES Journal of Marine Science 71: 648-665.

Seitz, R.D., K.E. Knick, and T.M. Davenport. and G.G. Saluta. 2017. Human influence at the coast: Upland and shoreline stressors affect coastal macrofauna and are mediated by salinity. Estuaries and Coasts. https://doi.org/10.1007/s12237-017-0347-6.

Sheaves, M., R. Baker, I. Nagelkerken, and R.M. Connolly. 2015. True value of estuarine and coastal nurseries for fish: incorporating complexity and dynamics. Estuaries and Coasts 38: 401-414. https:// doi.org/10.1007/s12237-014-9846-x.

Short, F.T., B. Polidoro, S.R. Livingstone, K.E. Carpenter, S. Bandeira, J. Sidik, H.P. Calumpong, et al. 2011. Extinction risk assessment of the world's seagrass species. Biological Conservation 144. Elsevier Ltd: 1961-1971. https://doi.org/10.1016/j.biocon.2011.04.010.

Short, F.T., R. Coles, M.D. Fortes, S. Victor, M. Salik, I. Isnain, J. Andrew, and A. Seno. 2014. Monitoring in the western Pacific region shows evidence of seagrass decline in line with global trends. Marine Pollution Bulletin 83: 408-416. https://doi.org/10.1016/j. marpolbul.2014.03.036.

Shriver, W.G., T.P. Hodgman, J.P. Gibbs, and P.D. Vickery. 2004. Landscape context influences salt marsh bird diversity and area requirements in New England. Biological Conservation 119: 545553. https://doi.org/10.1016/j.biocon.2004.01.016.

Silliman, B.R., and M.D. Bertness. 2004. Shoreline development drives invasion of Phragmites australis and the loss of plant diversity on New England salt marshes. Conservation Biology 18: 1424-1434.

Small, C., and R.J. Nicholls. 2003. A global analysis of human settlement in coastal zones. Journal of Coastal Research 19: 584-599.

Smith, L.A., and P. Chow-Fraser. 2010. Impacts of adjacent land use and isolation on marsh bird communities. Environmental Management 45: 1040-1051. https://doi.org/10.1007/s00267-010-9475-5.
Sobocinski, K.L., J.R. Cordell, and C.A. Simenstad. 2010. Effects of shoreline modifications on supratidal macroinvertebrate fauna on Puget sound, Washington beaches. Estuaries and Coasts 33: 699711. https://doi.org/10.1007/s12237-009-9262-9.

Spalding, M.D., S. Ruffo, C. Lacambra, I. Meliane, L. Zeitlin, C.C. Shepard, and M.W. Beck. 2014. The role of ecosystems in coastal protection: adapting to climate change and coastal hazards. Ocean and Coastal Management 90: 50-57. https://doi.org/10.1016/j. ocecoaman.2013.09.007.

Strayer, D.L., and S.E.G. Findlay. 2010. Ecology of freshwater shore zones. Aquatic Sciences 72: 127-163. https://doi.org/10.1007/ s00027-010-0128-9.

Strayer, D.L., S.E.G. Findlay, D. Miller, H.M. Malcom, D.T. Fischer, and T. Coote. 2012. Biodiversity in Hudson River shore zones: influence of shoreline type and physical structure. Aquatic Sciences 74: 597610. https://doi.org/10.1007/s00027-012-0252-9.

Studds, C.E., W.V. DeLuca, M.E. Baker, R.S. King, and P.P. Marra. 2012. Land cover and rainfall interact to shape waterbird community composition. PLoS One 7: 1-10. https://doi.org/10.1371/journal.pone. 0035969.

Sutton-Grier, A.E., K. Wowk, and H. Bamford. 2015. Future of our coasts: the potential for natural and hybrid infrastructure to enhance the resilience of our coastal communities, economies and ecosystems. Environmental Science and Policy 51. Elsevier Ltd: 137-148. https://doi.org/10.1016/j.envsci.2015.04.006.

Takekawa, J.Y., A.K. Miles, D.H. Schoellhamer, N.D. Athearn, M.K. Saiki, W.D. Duffy, S. Kleinschmidt, G.G. Shellenbarger, and C.A. Jannusch. 2006. Trophic structure and avian communities across a salinity gradient in evaporation ponds of the San Francisco Bay estuary. Hydrobiologia 567: 307-327. https://doi.org/10.1007/ s10750-006-0061-z.

Temmerman, S., P. Meire, T.J. Bouma, P.M.J. Herman, T. Ysebaert, and H.J. De Vriend. 2013. Ecosystem-based coastal defence in the face of global change. Nature 504: 79-83. https://doi.org/10.1038/ nature12859.

Thorne, K.M., B.J. Mattsson, J. Takekawa, J. Cummings, D. Crouse, G. Block, V. Bloom, et al. 2015. Collaborative decision-analytic framework to maximize resilience of tidal marshes to climate change. Ecology and Society 20: 30.

Toft, J.D., J.R. Cordell, C.A. Simenstad, and L.A. Stamatiou. 2007. Fish distribution, abundance, and behavior along city shoreline types in Puget sound. North American Journal of Fisheries Management 27: 465-480. https://doi.org/10.1577/M05-158.1.

Tourtellotte, G.H., and D.M. Dauer. 1983. Macrobenthic communities of the Chesapeake Bay. II. Lynnhaven roads, Lynnhaven Bay, Broad Bay, Linkhorn Bay. Internationale Revue der gesamten Hydrobiologie und Hydrographie 68: 59-72. https://doi.org/10. 1002/iroh.19830680105.

Turner, E.J., and T.E. Jordan. 2017. Integrating management needs into a Mid-Atlantic shorelines research project. Estuaries and Coasts. https://doi.org/10.1007/s12237-017-0261-y

Tyler, R.M., D.C. Brady, and T.E. Targett. 2009. Temporal and spatial dynamics of diel-cycling hypoxia in estuarine tributaries. Estuaries and Coasts 32: 123-145. https://doi.org/10.1007/ s12237-008-9108-x.

Unsworth, R.K.F., C.J. Collier, G.M. Henderson, and L.J. McKenzie. 2012. Tropical seagrass meadows modify seawater carbon chemistry: implications for coral reefs impacted by ocean acidification. Environmental Research Letters 7: 024026. https://doi.org/10. 1088/1748-9326/7/2/024026.

USEPA [US Environmental Protection Agency]. 2010. Chesapeake Bay total maximum daily load for nitrogen, phosphorus and sediment. US Environmental Protection Agency.

Valentine, J.F., and K.L. Heck. 1999. Seagrass herbivory: evidence for the continued grazing of marine grasses. Marine Ecology Progress Series 176: 291-302. 
van Katwijk, M.M., A.R. Bos, V.N. de Jonge, L.S.A.M. Hanssen, D.C.R. Hermus, and D.J. de Jong. 2009. Guidelines for seagrass restoration: Importance of habitat selection and donor population, spreading of risks, and ecosystem engineering effects. Marine Pollution Bulletin 58: 179-188. https://doi.org/10. 1016/j.marpolbul.2008.09.028.

Vitousek, P.M., H.A. Mooney, J. Lubchenco, and J.M. Melillo. 1997. Human domination of Earth's ecosystems. Science 277: 494499.

Walker, R., B. Bendell, and L. Wallendorf. 2011. Defining engineering guidance for living shoreline projects. In Coastal Engineering Practice, 1064-1077. https://doi.org/10.1061/41190(422)86.

Waycott, M., B.J. Longstaff, and J. Mellors. 2005. Seagrass population dynamics and water quality in the Great Barrier Reef region: a review and future research directions. Marine Pollution Bulletin 51: 343-350. https://doi.org/10.1016/j.marpolbul.2005.01.017.

Waycott, M., C.M. Duarte, T.J.B. Carruthers, R.J. Orth, W.C. Dennison, S. Olyarnik, A. Calladine, et al. 2009. Accelerating loss of seagrasses across the globe threatens coastal ecosystems. Proceedings of the National Academy of Sciences of the United States of America 106: 12377-12381.

Weis, J.S., P. Weis, and T. Proctor. 1998. The extent of benthic impacts of CCA-treated wood structures in Atlantic coast estuaries. Archives of Environmental Contamination and Toxicology 34: 313-322.

Weisberg, S.B., J.A. Ranasinghe, D.M. Dauer, L.C. Schaffner, R.J. Diaz, and J.B. Frithsen. 1997. An estuarine benthic index of biotic integrity (B-IBI) for Chesapeake Bay. Estuaries 20: 149-158. https://doi. org/10.2307/1352728.
Weller, D.E., T.E. Jordan, D.L. Correll, and Z. Liu. 2003. Effects of landuse change on nutrient discharges from the Patuxent River watershed. Estuaries 26: 244-266. https://doi.org/10.1007/BF02695965

Wigand, C.W., and C.T. Roman. 2012. North Atlantic coastal tidal wetlands. In Wetland habitats of North America. Ecology and conservation concerns, ed. D.P. Batzer and A.H. Baldwin, 13-28. Berkley: University of California Press.

Wigand, C., M. Finn, S. Findlay, and D. Fischer. 2001. Submersed macrophyte effects on nutrient exchanges in riverine sediments. Estuaries 24: 398-406.

Wilcox, D.A. 2012. Response of wetland vegetation to the post-1986 decrease in Lake St. Clair water levels: Seed-bank emergence and beginnings of the Phragmites australis invasion. Journal of Great Lakes Research 38. Elsevier B.V.: 270-277. https://doi.org/10.1016/ j.jglr.2012.02.007.

Williams, S.J. 2013. Sea-level rise implications for coastal regions. Journal of Coastal Research 63: 184-196. https://doi.org/10.2112/ SI63-015.1.

Wilson, M.D., B.D. Watts, and D.F. Brinker. 2007. Status review of Chesapeake Bay marsh lands and breeding marsh birds. Waterbirds 30: 122-137. https://doi.org/10.1675/1524-4695(2007) 030[0122:SROCBM]2.0.CO;2.

Zedler, J.B. 2004. Compensating for wetland losses in the United States. Ibis 146: 92-100.

Zedler, J.B. 2017. What's new in adaptive management and restoration of coasts and estuaries? Estuaries and Coasts 40. Estuaries and Coasts: 1-21. https://doi.org/10.1007/s12237-016-0162-5. 